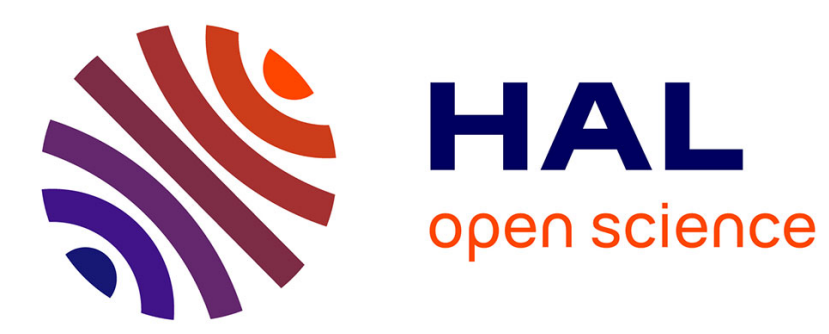

\title{
Photochemical studies on bis-sulfide and -sulfone tethered polyenic derivatives
}

Simon Guélen, Max Blazejak, Lise-Marie Chamoreau, Arnaud Huguet, Sylvie

Derenne, François Volatron, Virginie Mouriès-Mansuy, Louis Fensterbank

\section{- To cite this version:}

Simon Guélen, Max Blazejak, Lise-Marie Chamoreau, Arnaud Huguet, Sylvie Derenne, et al.. Photochemical studies on bis-sulfide and -sulfone tethered polyenic derivatives. Organic \& Biomolecular Chemistry, 2017, 15 (19), pp.4180-4190. 10.1039/C7OB00551B . hal-01525844

\section{HAL Id: hal-01525844 https://hal.sorbonne-universite.fr/hal-01525844}

Submitted on 22 May 2017

HAL is a multi-disciplinary open access archive for the deposit and dissemination of scientific research documents, whether they are published or not. The documents may come from teaching and research institutions in France or abroad, or from public or private research centers.
L'archive ouverte pluridisciplinaire HAL, est destinée au dépôt et à la diffusion de documents scientifiques de niveau recherche, publiés ou non, émanant des établissements d'enseignement et de recherche français ou étrangers, des laboratoires publics ou privés. 


\title{
Photochemical Studies on Bis-Sulfide and -Sulfone Tethered Polyenic Derivatives
}

\author{
Simon Guélen, ${ }^{a}$ Max Blazejak, ${ }^{a}$ Lise-Marie Chamoreau, ${ }^{a}$ Arnaud Huguet, ${ }^{b}$ Sylvie Derenne, ${ }^{\mathrm{b}}$ \\ François Volatron, ${ }^{c}$ Virginie Mouriès-Mansuy*a and Louis Fensterbank*a \\ This study focusses on the [2+2]-photocycloaddition of symmetric polyenic system tethered by an aryl bis-sulfide or sulfone \\ platform. Using direct irradiation or photosensibilization, no expected ladderane product was isolated. In most cases, only \\ tricyclic products including a single cyclobutane moeity were formed. Irradiation of bis-acrylic precursors in water with \\ encapsulation by a host (cyclodextrin or cucurbituril) provided a stereoselective access to valuable cyclobutyl adducts.
}

\section{Introduction}

\section{Context}

Ladderanes are fascinating molecules. By exhibiting two or more linearly fused cyclobutanes, they draw the attention of the organic chemist who is not used to encounter this type of molecular structures. ${ }^{1}$ The high ring strain of these edifices gives them potentially interesting electronic and optical properties which are of interest for physical chemists and theoreticians. ${ }^{2}$ Interestingly, ladderane lipids are present in nature. They have been identified in anammox bacteria performing anaerobic ammonium oxidation (anammox), where they form impermeable intracytoplasmic membranes, the anammoxosome. ${ }^{3}$ The anammoxosome protects the bacteria from the formation of highly toxic species like hydrazine and hydroxylamine generated as intermediates during the anammox process. This process was discovered two decades ago and it seems to be an important component of the nitrogen biogeochemical cycle. ${ }^{4}$

Because of their intriguing architecture and properties, ladderanes have elicited synthetic developments. The latter have culminated in the total syntheses by Corey of the naturally occuring ladderane pentacycloanammoxic acid in $2004^{5}$ and $2006^{6}$ which was isolated in 2002 by Sinninghe Damsté and coworkers. ${ }^{7}$ These total syntheses are outstanding tour de force and it is only very recently that the group of Burns came up with a second similarly elegant and efficient total synthesis of natural 3- and 5-ladderanes. ${ }^{8}$ Both approaches rely on the $[2+2]$ photochemical cycloaddition which is the obvious methodology to make 4-membered rings ${ }^{9}$ but they also involve cyclobutene building blocks which are not straightforward to prepare. ${ }^{10}$

\section{Ladderanes via multiple [2+2] cycloaddition}

Assembling the ladderane framework in a single synthetic operation has constituted a highly stimulating challenge for a lot of groups and some important findings have been made in

\footnotetext{
a. Sorbonne Universités, UPMC Univ Paris 06, CNRS, UMR 8232 Institut Parisien de Chimie Moléculaire, 4 place Jussieu, 75252 Paris cedex 05, France

b. Sorbonne Universités, UPMC Univ Paris 06, CNRS, EPHE, UMR 7619 METIS, 4 place Jussieu, 75252 Paris cedex 05, France

c. Sorbonne Universités, UPMC Univ Paris 06, CNRS, UMR 7616 Laboratoire de Chimie Théorique, 4 place Jussieu, 75252 Paris cedex 05, France

+ Footnotes relating to the title and/or authors should appear here.

Electronic Supplementary Information (ESI) available: [details of any supplementary information available should be included here]. See DOI: 10.1039/x0xx00000x
}

polycyclization strategies via [2+2] photocycloaddition. Prototype systems have in fact already been devised and are based on the Schmidt topochemical principle ${ }^{11}$ transposed to solutions, which consists in fixing two polyenic chains in a coplanar configuration and separated by a 350 to at most 420 pm distance. ${ }^{12}$ An early and illustrative example was given by Hopf in $1995^{13}$ who used a cyclophane anchor to ensure the adequate arrangement of the polyenic systems. A high yield (83\%) of a five fused cyclobutane unit corresponding to a [5]ladderane framework was obtained after irradiation (450W Hg high pressure lamp) at room temperature in methanol (Scheme 1). MacGillivray proposed a supramolecular approach, relying on the cocrystallization of a resorcinol derivative with pyridine ended polyene systems. ${ }^{14}$ Upon irridiation (broadband Hg lamp) in the solid state, the obtained crystals undergo quantitative $[2+2]$ cycloaddition on gram amounts (Scheme 1).

Other reports of multiple [2+2] cycloadditions have confirmed the viability of such an approach. ${ }^{15}$

Hopf, 1995

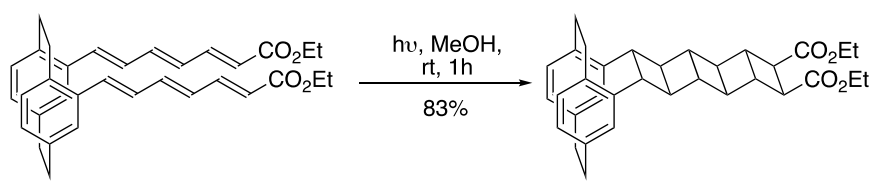

MacGillivray, 2004

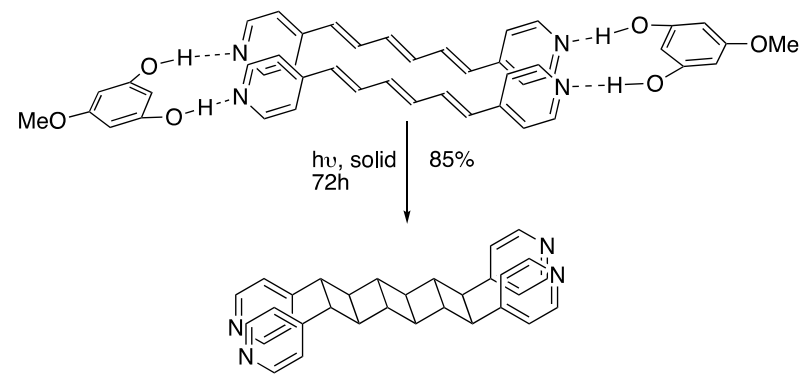

Scheme 1. Polycyclizations leading to ladderanes

\section{Our objective}

Recently, we have initiated a research program dealing with the development of alternative platforms which would promote the polycyclization process and provide more readily functionalizable anchors for further elaboration. Sulfur based linkers which should be easily disposable after the ladderane framework formation drew our attention. We initiated this study by first modeling the proposed substrates. 


\section{Results and discussions}

\section{Calculations}

While only few theoretical studies have been published on ladderane frameworks focusing on their heats of formation as well as putative mechanisms of formation, ${ }^{16}$ we have recently engaged into a theoretical analysis of ladderane at high computational level. Our findings on an unsubstituted hydrocarbon species as well as on new phenyl bis-sulfone and bis-sulfide tethered substrates are discussed below.

\section{Unsusbtituted ladderane}

First, we focused on polyunsaturated systems of formula $\mathrm{C}_{12} \mathrm{H}_{16}$. Acyclic (I-Acyc), monocyclic (I-Mono, three isomers), tricyclic (ITric) and pentacyclic (I-Pent) isomers (Figure 1) were optimized and characterized at two levels of calculation. The B3LYP level with the $6-31 \mathrm{G}(\mathrm{d}, \mathrm{p})$ basis set was first used. The structures were reoptimized at the more sophisticated PW1PW91 level with the pVT basis set. Then, single point calculations were performed at the $\operatorname{CCSD}(T)$ level on both sets of optimized structures. The results are given in Table 1.
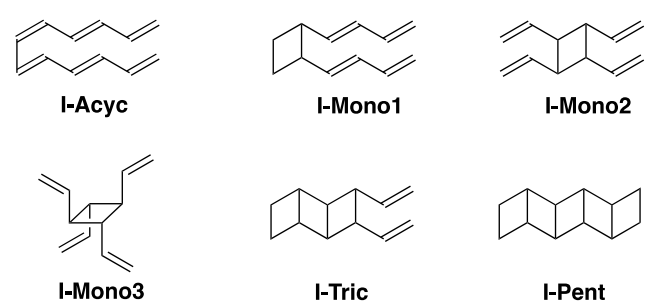

Figure 1. Unsubstituted isomers under study

The values at the PW1PW91 level differ noticeably from those at the B3LYP level (Table 1) and are always lower. However, the two sets of results become almost identical when $\operatorname{CCSD}(T)$ calculations are performed on the geometries obtained at the two DFT (B3LYP or PW1PW91) levels. In most cases, the CCSD(T) relative energies are also lower than the DFT ones. ${ }^{17}$

As a consequence, calculations in the following series will be undertaken at the $\operatorname{CCSD}(\mathrm{T})$ level with the geometries optimized at the B3LYP level.

\section{Aryl bis-sulfone and aryl bis-sulfide platform study}

The theoretical study of the ladderane formation from the cyclization of II-Acyc was also carried out. Seven isomers were studied with zero (II-Acyc), one (III-Mono), three (II-Tric), or five (II-Pent) cyclobutane rings in the structure. Similar treatment was achieved from aryl bis-sulfide III-Acyc. Their structures and relative energies are given in Figure 2 and Tables 2 and 3.

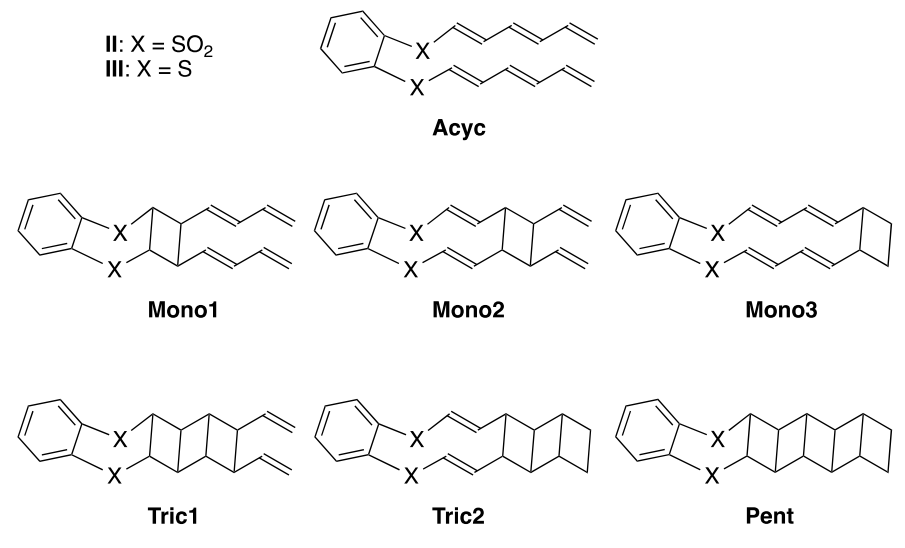

Figure 2. Structures of the computed isomers of the bis-sulfone (II) and bis-sulfide (III) platforms 
Table 1a. Relative energies (in kcal/mol) of the computed isomers of the unsubstituted system at the B3LYP and CCSD(T) levels

\begin{tabular}{|l|l|l|l|l|l|l|}
\hline & I-Acyc & I-Mono 1 & I-Mono 2 & I-Mono 3 & II-Tric & II-Pent \\
\hline$\Delta$ E B3LYP & 0.0 & -6.8 & 3.5 & 7.8 & 16.7 & 21.2 \\
$\Delta$ E CCSD(T) & $\mathbf{0 . 0}$ & -15.3 & -9.6 & -6.1 & 1.9 & 4.2 \\
\hline$\Delta$ E mPW1PW91 & 0.0 & -11.8 & -2.6 & -16.8 & 6.1 & 5.7 \\
$\Delta$ E CCSD(T) & $\mathbf{0 . 0}$ & -14.2 & -9.4 & -6.2 & 3.4 & 7.9 \\
\hline
\end{tabular}

Table 2. Relative energies (in $\mathrm{kcal} / \mathrm{mol}$ ) of the computed isomers of the arylbissulfone system at the B3LYP and CCSD(T) levels

\begin{tabular}{|l|l|l|l|l|l|l|l|}
\hline & II-Acyc & II-Mono1 & II-Mono2 & II-Mono3 & II-Tric1 & II-Tric2 & II-Pent \\
\hline$\Delta \mathrm{E}$ B3LYP & 0.0 & -4.8 & 21.7 & 5.0 & 17.8 & 29.3 & 21.7 \\
$\Delta \mathrm{E} \operatorname{CCSD}(\mathrm{T})$ & $\mathbf{0 . 0}$ & $\mathbf{- 1 5 . 3}$ & $\mathbf{6 . 8}$ & $\mathbf{- 4 . 8}$ & $\mathbf{1 . 8}$ & $\mathbf{1 3 . 8}$ & $\mathbf{3 . 7}$ \\
\hline
\end{tabular}

Table 3. Relative energies (in $\mathrm{kcal} / \mathrm{mol}$ ) of the computed isomers of the arylbissulfide system at the B3LYP and CCSD(T) levels

\begin{tabular}{|l|l|l|l|l|l|l|l|}
\hline & III-Acyc & III-Mono1 & III-Mono2 & III-Mono3 & III-Tric1 & III-Tric2 & III-Pent \\
\hline$\Delta$ E B3LYP & 0.0 & -1.8 & 24.4 & 9.2 & 20.9 & 31.4 & 28.7 \\
E CCSD(T) & $\mathbf{0 . 0}$ & -15.0 & $\mathbf{7 . 0}$ & -3.7 & $\mathbf{1 . 3}$ & $\mathbf{1 2 . 7}$ & $\mathbf{3 . 5}$ \\
\hline
\end{tabular}

As in the previous case, the relative energies are much lower at the $\operatorname{CCSD}(T)$ level in the bis-sulfone and bis-sulfide series compared to those obtained at the B3LYP level. Among the three monocyclic structures, II-Mono2 and III-Mono2 are the less stable ones, probably because of the loss of any conjugation between the $\mathrm{C}-\mathrm{C}$ double bonds. Interestingly also, 10membered ring isomers II-Tric2 and III-Tric3 are the less stable of the series. Finally, in both series, the pentacyclic structure IIPent or III-Pent are rather close in energy to the corresponding Acyc precursors I ( $\Delta \mathrm{E} \approx 3.5 \mathrm{kcal} / \mathrm{mol}$, Tables 2 and 3 ).

These findings suggest that II-Acyc or III-Acyc and congeners could therefore be good candidates to access to pentacyclic ladderanes.

\section{Preparation of precursors}

We devised a straightforward preparation of the photocycloaddition precursors. Starting from 1,2-benzenedithiol 1 which is commercially available or can be made on large scale, deprotonation with $\mathrm{n}$-BuLi and controlled addition on $\beta$ iodoacrylate provided a quantitative yield of bis-acrylate 2 . The competitive intramolecular addition of a thiolate anion on a branched acrylate unit could be suppressed by working in cold $\left(-78^{\circ} \mathrm{C}\right)$ and concentrated conditions (see Experimental). Homologation of the acrylate was achieved by a sequence of DIBAL reduction, allylic oxidation (to give bis-aldehyde 3 in $72 \%$ yield) and Horner Wadsworth Emmons (HWE) olefination which delivered bis-diene 4 in $63 \%$ overall yield. Similarly, bis-triene 6 was obtained in $54 \%$ overall yield. The latter could be oxidized to the bis-sulfone precursor 6-O in quantitative yield using 4.5 equiv of MCPBA. Worthy of note, all these polyene substrates proved to be quite stable, notably upon silica gel chromatography. Some of them crystallized fairly easily by pentane diffusion in a dichloromethane solution of the polyene substrate and a X-ray diffraction (XRD) analysis was obtained for 4, 5, 6 and 6-0.

\section{X-ray diffraction analyses of precursors}

All the XRD structures share common features and, contrary to the previous calculations, show no overlap of the ortho ene units whatever the number of ene units (from the acrylate to the triene acrylate). Instead, unsaturated arms lie in opposite directions as illustrated by the structures of 4 and 6-0 on Scheme 2 . In some cases $(4,6,6-0)$, the chains of two different precusors are almost coplanar and parallel. Some weak interactions $\mathrm{C}-\mathrm{H}$...O interactions ${ }^{18}$ also take place between the hydrogen atoms of the enes and the $\mathrm{O}$ atom of the ester function, leading to a distance between polyene arms of more than $5 \AA$ A. Despite these findings, we attempted the photocycloaddition of the precursors in solution assuming that some conformations of cyclization could be reached. 

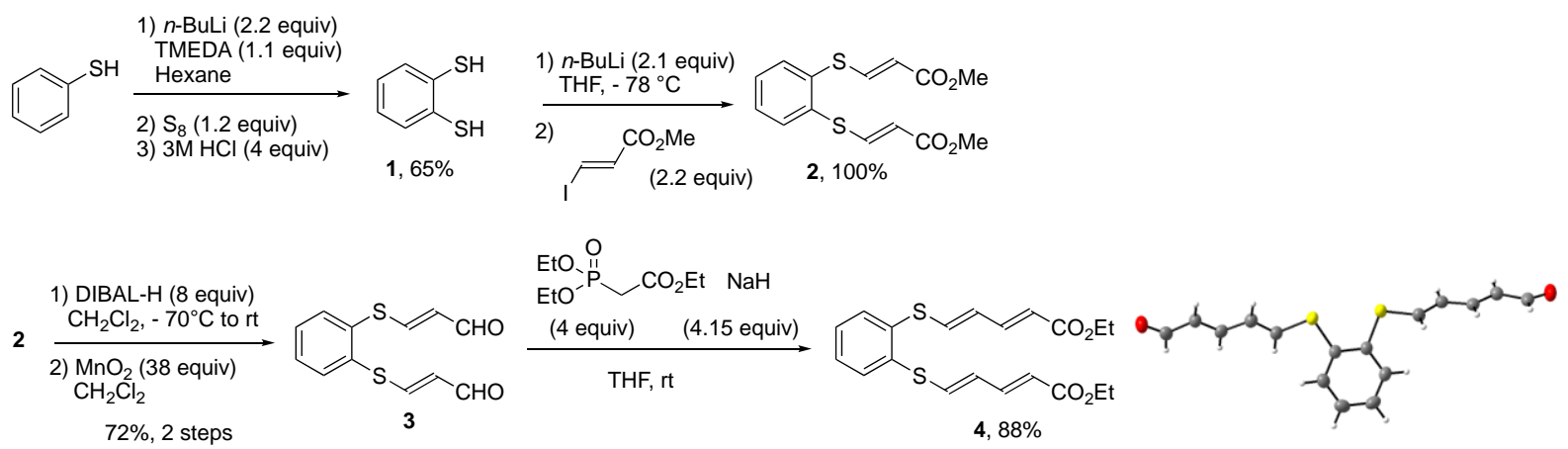

$4 \underset{79 \%, 2 \text { steps }}{\stackrel{\text { as from } 2 \text { to } 3}{\longrightarrow}}$
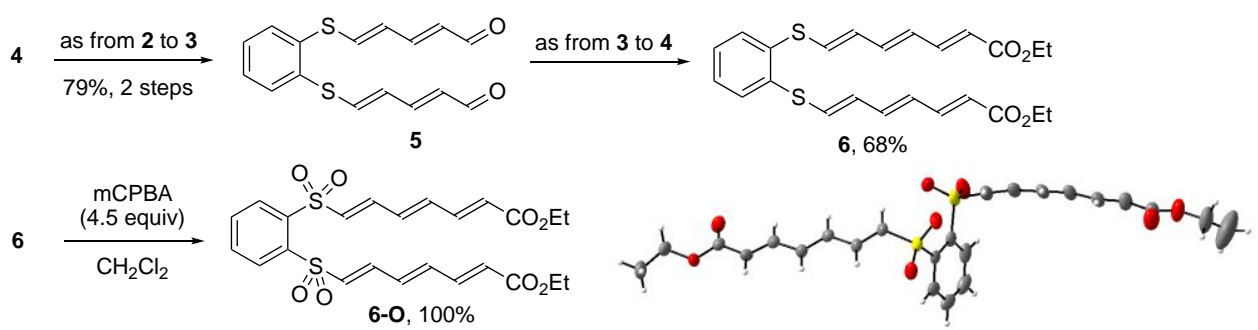

Scheme 2. Synthesis of substrates

\section{UV absorbance}

We measured the UV spectra of the polyene substrates $\mathbf{2}, \mathbf{4}, \mathbf{6}$ and 6-O and values are given in Table 4. Logically, a bathochrom effect was observed by adding $C=C$ units, from $\lambda_{\max }=281 \mathrm{~nm}$ for $\mathbf{2}$ to $356 \mathrm{~nm}$ for $\mathbf{6}$ which was accompanied by a hyperchrome effect. Interestingly, also the replacement of the sulfide linker by a sulfone one led to a hypsochrome effect: a diminution of $50 \mathrm{~nm}$ is observed between from the sulfide to the corresponding sulfone, suggesting that the sulfone function attenuates the conjugation.

Table 3. UV data of of polyenic precursors

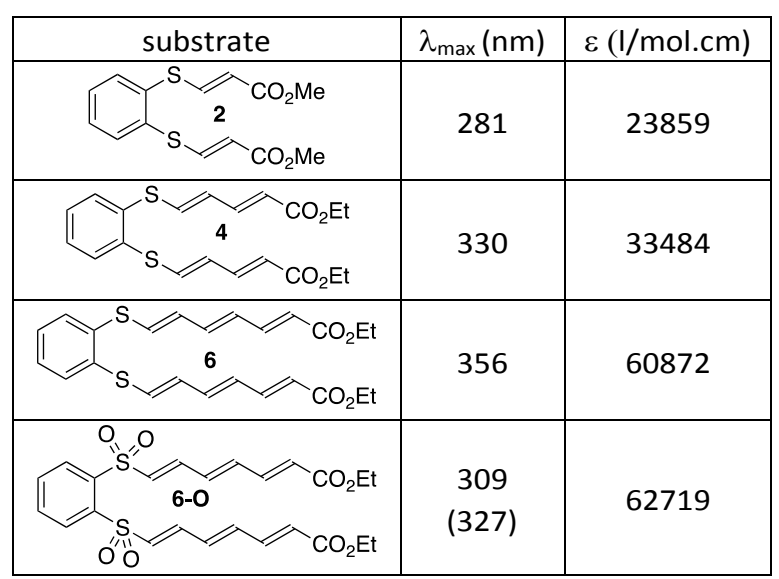

\section{Preliminary Irradiation results}

We first irradiated a $\mathrm{CD}_{3} \mathrm{CN}$ solution of precursor $\mathbf{2}$ in a Rayonet reactor. The latter converted very slowly to the $[2+2]$ cycloaddition product $\mathbf{7}$ and in an incomplete fashion since the main competitive pathway was the isomerization of $\mathbf{2}$ to provide the $E, Z$ and $Z, Z$ isomers (Scheme 3). ${ }^{\#}$ The proposed relative configuration of $\mathbf{7}$ is based on our subsequent findings (see below).

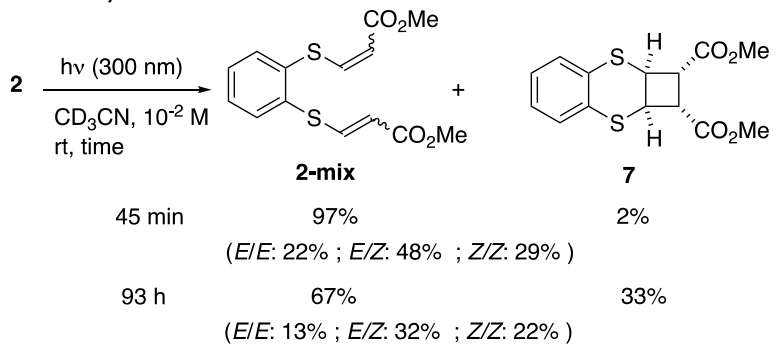

Scheme 3. Direct irradiation of bis-monoene 2

We looked at the photocycloaddition of bis-diene 4 which proved to be more reactive since a total conversion was observed in $1 \mathrm{~h}$ (Scheme 4). Two stereoisomeric cyclobutyl products products were isolated. The major one (8-sym, 31\%) displayed half of the expected signals by ${ }^{1} \mathrm{H}$ and ${ }^{13} \mathrm{C} N M R$ patterns which suggested a symmetric structure contrary to the second dissymmetric product one (8-dis, $21 \%$ ) for which all resonances were distinct. While the relative configuration of 8sym was deduced from findings detailed below, NOESY experiments on 8-dis allowed us to propose a syn-trans-anti configuration. ${ }^{19}$ 


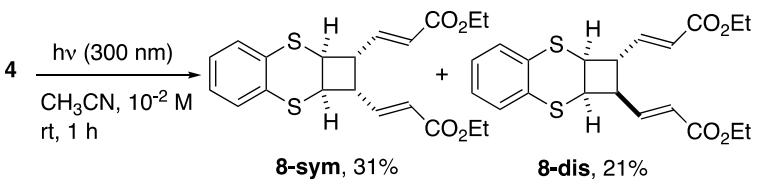

Scheme 4. Direct irradiation of bis-diene 4

We also wished to examine the corresponding triene precursor 6. Similar behaviour as for $\mathbf{4}$ was observed under irradiation (Scheme 5). In less than one hour, two stereoisomeric cyclobutane derivatives, 9-sym (45\%) and 9-dis (25\%), were formed displaying analogous ${ }^{1} \mathrm{H}$ NMR patterns as before. No polycyclobutane product was isolated from these reactions.

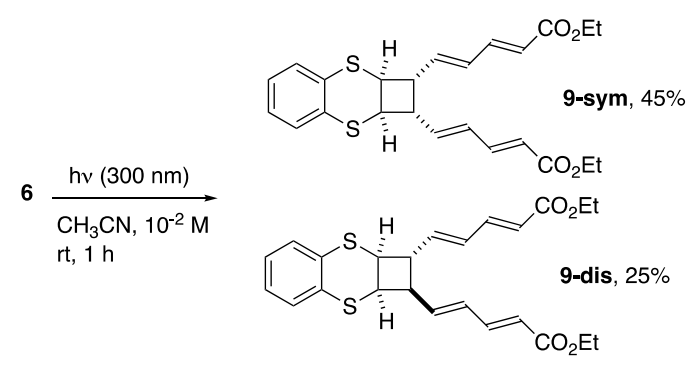

Scheme 5. Direct irradiation of bis-triene 6

It was interesting to compare these results with the corresponding 6-0 precursor (Scheme 6). In that case, irradiation at $300 \mathrm{~nm}$ led to a new mixture of compounds, namely 9-0-sym as major component and two unpreviously observed type of products, such as symmetric 9-0-sym' and macrocycle $\mathbf{1 0}$. The structure of $\mathbf{1 0}$ was unambiguously determined thanks to XRD analysis (see Figure 3 ). ${ }^{\ddagger}$ Also, we observed that upon standing at rt for 10 days, 9-O-sym' smoothly isomerized into $\mathbf{1 0}$ presumably via multiple Cope rearrangement. ${ }^{2 \mathrm{~d}, 20}$ This observation allowed to safely attribute the anti-cis-anti configuration to $C_{2}$-symmetric 9-0-sym' derivative.

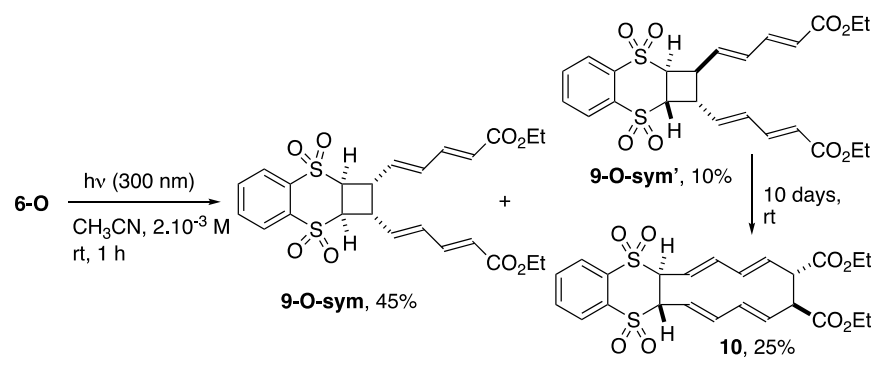

Scheme 6. Direct irradiation of bis-triene sulfones 6-0

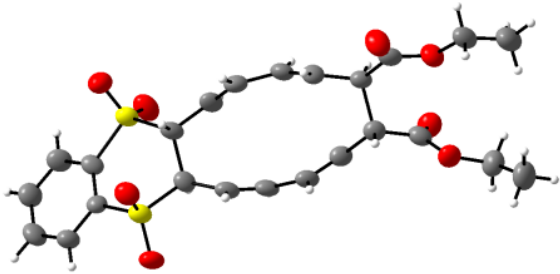

Figure 3. XRD structure of 10

Confronted to these rather frustrating though interesting findings, we questioned several aspects of our methodology. First, was our irradiation system adequate? To check this, we resynthesized Hopf's precursor of Scheme 1. Upon irradiation in the Rayonet reactor in conditions similar to Hopf, we obtained the same result consisting of the formation of the [5]-ladderane in $85 \%$ yield. This confirmed the validity of our preliminary experiments.

\section{Exploring other substrates and conditions}

\section{Copper(I) catalysis}

We tested the use of the copper(I) [(CuOTf $)_{2} \mathrm{C}_{6} \mathrm{H}_{6}$ ] complex first reported by Kochi, which is known to catalyse [2+2] photocycloadditions ${ }^{21}$ thanks to the formation of a very stable photoexcitable complex with the alkene partners. Upon these catalytic conditions, precursor $\mathbf{2}$ led almost exclusively to the mixture of alkene isomerization products 2-mix (Scheme 7).

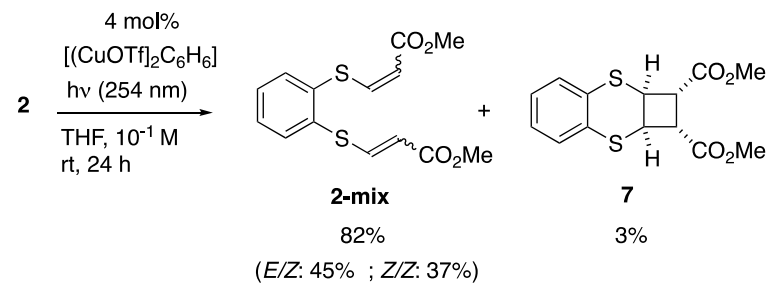

Scheme 7. Copper(I) photocatalysis on $\mathbf{2}$

With bis-triene 6 and $8 \mathrm{~mol} \%$ of [(CuOTf $)_{2} \mathrm{C}_{6} \mathrm{H}_{6}$ ], a complex mixture was obtained which precluded further investigation with this catalytic system.

\section{Photosensitizing}

Although our lighting source seemed appropriate, we still wondered if milder conditions would not be more productive. We turned our attention to the use of photosensitizers which could transfer energy and promote the [2+2] photocycloaddition process. Some examples have been reported with the use of $\mathrm{Ru}(\mathrm{II}){ }^{22}$ and $\operatorname{Ir}(\mathrm{III})^{23}$ upon visible light (28 W fluorescent bulb) irradiation. At their excited triplet state, these metal complexes are prone to single electron transfer (SET) but also to energy transfer. ${ }^{22 a}$ We focused on precursor 6 and aimed at the latter phenomenon anticipating no obvious 
SET could take place between this substrate and the excited photocatalyst in the absence of sacrificial electron donor or acceptor. Upon visible light irradiation in DMF in the presence of $5 \mathrm{~mol} \%$ of $\mathrm{Ru}(\mathrm{bpy})_{3} \mathrm{Cl}_{2} \cdot 6 \mathrm{H}_{2} \mathrm{O}$, a mixture of 9-sym and 9-dis (44\%, 25\%) was smoothly obtained. Interestingly, by using blue LEDS, with or without photocatalyst, we also obtained the same mixture. In all cases, no ladderane was observed.

We also considered the possibility to have an internal photosensitizing function on the substrate ${ }^{24}$ so we prepared bisphenylketone $\mathbf{1 1}$ from bis-aldehyde $\mathbf{5}$ using a HWE olefination ( $54 \%$ yield). UV spectrum of 11 showed two big bands at 288 and $388 \mathrm{~nm}$. Its irradiation at $350 \mathrm{~nm}$ in acetonitrile and methanol for $15 \mathrm{~h}$ did not show any conversion (Scheme 8). Based on the very elegant chemistry developed by Yoon, ${ }^{25}$ we also considered using photoredox catalysis to assemble the ladderane framework. Using $\mathrm{Ru}(\mathrm{bpy})_{3}{ }^{2+}$ as photocatalyst and Hunig's base as a reductive quench, a mixture of polyunsaturated adducts suggesting oligomerization processes was observed.

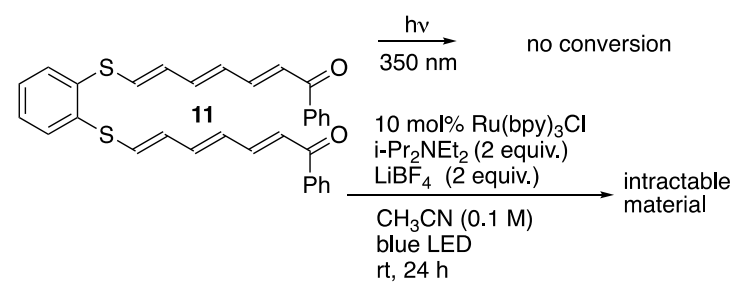

Scheme 8. Irradiation of bis-phenylketone 6

\section{Encapsulation}

A number of reports have shown that [2+2] photocycloadditions can be accomplished by using a cyclodextrin or a curcubituryl guest. ${ }^{26}$ Using water as solvent, the polyene substrate interacts with the inner hydrophobic wall of the guest. In this confined space, the substrate has restricted motion which favors the ring closure process.

We initially concentrated on the monoene substrate $\mathbf{2}$ and the corresponding diacid 2-OH obtained in $93 \%$ yield by saponification with $\mathrm{LiOH}$ in $\mathrm{THF} / \mathrm{H}_{2} \mathrm{O}$. With substrate $\mathbf{2}$, a host effect was observed with $\alpha-, \beta$ - and $\gamma$-CDs since higher proportions of products were obtained compared to reactions operated in pure water (Scheme 9). We also found that the $\beta$ $C D$ provided the most favorable environment for the $[2+2]$ cycloaddition. After $24 \mathrm{~h}$, product 7 was present as $58 \%$ of the reaction mixture; after extended reaction time (93 h), only 7 was observed. The use of the cucurbit[8]uril ( $\mathrm{CB}[8]$ ) host did not bring any improvement and showed that the medium concentration was a key factor since by diluting, the proportion of product $\mathbf{7}$ could become major. Nevertheless, encapsulation brought significant improvement compared to our initial conditions (see Scheme 3).

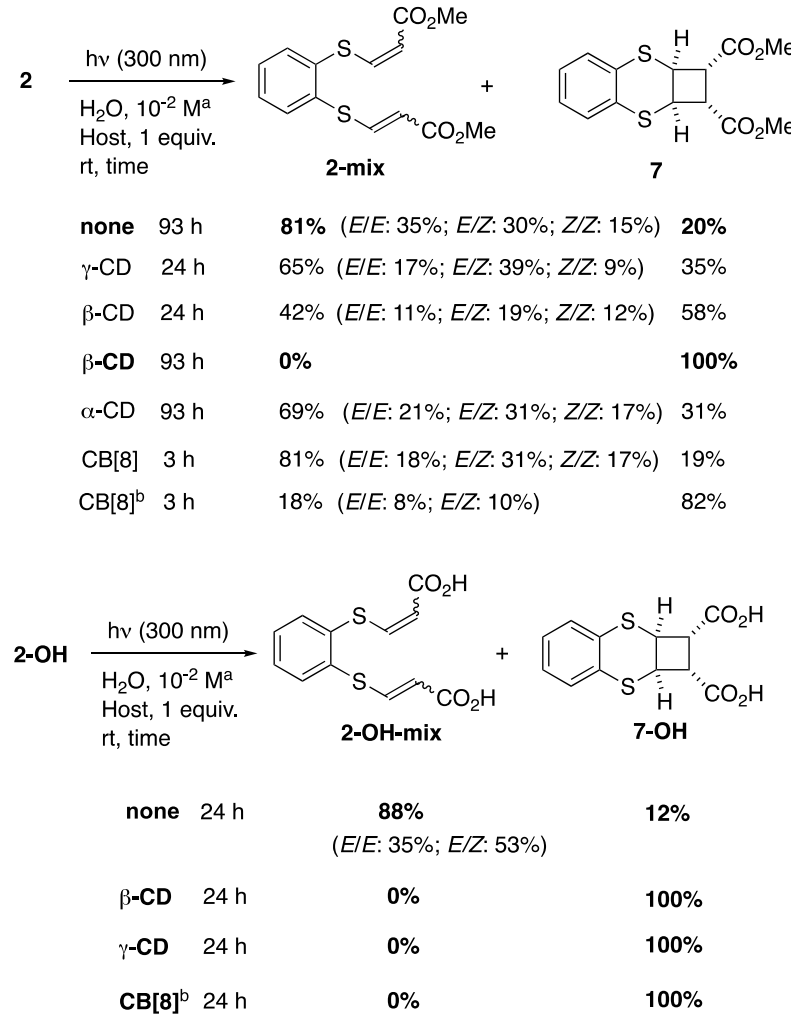

${ }^{\text {a }}$ All reactions run on a $(0.08-0.16 \mathrm{mmol})$ scale. Ratios determined by ${ }^{1} \mathrm{H}$ NMR after extraction (see SI).

${ }^{b}$ Reaction run at $1.610^{-4} \mathrm{M}$

Scheme 9. Irradiation of bis-monoenes $\mathbf{2}$ and $\mathbf{2 - O H}$ in water in the presence of a host

Better results were also obtained from diacid precursor 2-OH. While, in pure water, very little cyclobutyl 7-OH was formed, the use of a guest (cyclodextrin or cucurbituril) allowed the exclusive formation of 7-OH. A preparative experiment was run and led to a $69 \%$ yield of isolated product $7-\mathbf{O H}$. Diacid $7-\mathbf{O H}$ was also obtained from the saponification of 7 with $\mathrm{NaOH}$ in a mixture of THF and water (Scheme 10). Suitable crystals of 7-OH for a XRD analysis ${ }^{\ddagger}$ were obtained which allowed to cross-check the syn-trans-syn relative configuration of cyclobutyl derivatives $\mathbf{7 - O H}$ and $\mathbf{7}$ obtained in all the photochemical experiments (see Schemes 3 and 9).

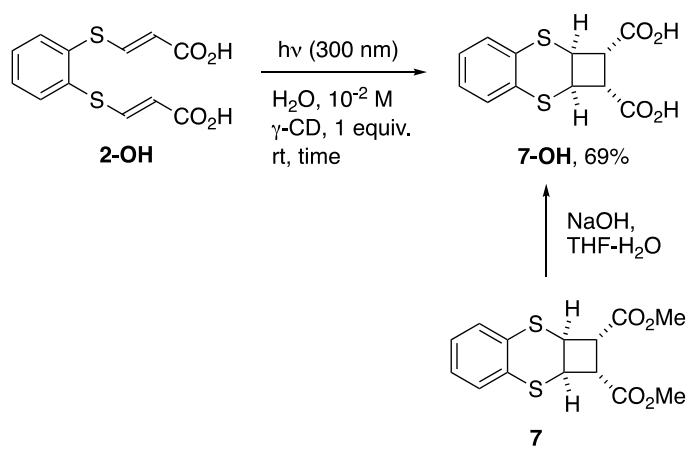

Scheme 10. Irradiation of $\mathbf{2 - O H}$ and configuration cross-check 
Encouraged by these findings, and also because the intermolecular formation of some ladderanes was reported on using $\mathrm{CB}[8],{ }^{27}$ we examined the longer systems such as bis-diene and bis-triene ester or acid substrates. In most cases, no conversion was observed and suspected that encapsulation was only partial (only one arm of the substrate) or could also involve two hosts.

\section{Conclusions}

This study has aimed at defining a new easily introduced and disposable tether between two symmetrical polyenic chains which could lead to ladderanes afer multiple [2+2] cycloadditions. Sulfur based platforms were explored. The corresponding polyenic precursors were readily synthesized and proved to be very stable. Although, their solid state structures did not exhibit a favourable spatial arrangement for intramolecular $[2+2]$ cycloaddition, $\operatorname{CCSD}(T)$ calculations suggested a moderate enthalpic cost for the ladderane formation which conducted us to photochemical experiments in various conditions (direct irradiation, photosensitization, encapsulation). No ladderane could be isolated from all these attempts. Instead, all precursors generally provided monocycobutyl photo adducts. Thanks to the use of a host like a cyclodextrin or a cucurbituril in water, encapsulation led to a selective photocycloaddition process yielding a cyclobutyl product as a single diastereomer. The latter could serve after scale-up as a valuable building block for further elaboration on the ladderane route.

\section{Experimental}

\section{Computational procedure}

The Gaussian set of programs has been used throughout. ${ }^{28}$ Geometry optimization and frequencies calculations were done at the B3LYP/631G** and mPW1/PW91 levels. ${ }^{29}$ In order to get more reliable results, the correlation energies of the extrema were taken into account at the more sophisticated $\operatorname{CCSD}(T)$ level. ${ }^{30}$

\section{Experimental: generalities}

Unless otherwise noted, reactions were carried out under argon atmosphere. Methanol was dried overnight over freshly activated molecular sieves ( $4 \AA$ ), THF and diethyl ether were distillated from sodium/benzophenone. Other reagents and chemicals were purchased from commercial sources and used as received. Infrared (IR) spectra were recorded on a Bruker Tensor 27 (ATR diamond) spectrophotometer. Melting points were determined on a melting point apparatus SMP3 (Stuart scientific) and are uncorrected. NMR spectra were recorded at room temperature on Bruker AVANCE 600,400 or 300 spectrometers. Chemical shifts $(\delta)$ are reported in ppm and coupling constants $(J)$ are given in Hertz $(\mathrm{Hz}) .{ }^{1} \mathrm{H}$ and ${ }^{13} \mathrm{C}$ NMR assignments were based on COSY, HSQC and HMBC experiments. Abbreviations used for peak multiplicity are: $s$ (singlet); bs (broad singlet); d (doublet); t (triplet); q (quartet); $p$ (quintuplet), $\mathrm{m}$ (multiplet) and for assignments: $\mathrm{cp}$ (cyclopropyl); cb (cyclobutyl); cpe (cyclopentyl); ch (cyclohexyl). High resolution mass spectrometry was performed on a
microTOF (ESI). Thin layer chromatography (TLC) was performed on Merck silica gel $60 \mathrm{~F} 254$ and detected with a UV lamp $(\lambda=254 \mathrm{~nm})$ and $\mathrm{KMnO}_{4}$ or $p$-anisaldehyde staining. Flash column chromatography was performed on silica Geduran ${ }^{\circledR} \mathrm{Si}$ $60 \AA(40-63 \mu \mathrm{m})$.

\section{General procedures}

GP1: Diester DIBAL-H reduction and diol $\mathrm{MnO}_{2}$ oxidation

To a stirred solution of diester (1 equiv) in DCM (0.1 M) at - 78 ${ }^{\circ} \mathrm{C}$ was added DIBAL-H (1 $\mathrm{M}$ in DCM, 8 equiv) dropwise and the reaction mixture was stirred at $0{ }^{\circ} \mathrm{C}$ for $2 \mathrm{~h}$. The reaction was quenched with saturated Rochelle's salt solution and extracted with DCM. The combined organic layers were washed with water, dried over $\mathrm{MgSO}_{4}$, filtered and concentrated under reduced pressure to give the corresponding diol. To a stirred solution of this diol (1 equiv) in DCM $(0.05 \mathrm{M})$ at rt was added $\mathrm{MnO}_{2}$ (38 equiv) portionwise and the mixture was stirred at $\mathrm{rt}$ for $12 \mathrm{~h}$. The reaction mixture was filtered on a Celite ${ }^{\bullet}$ pad, washed with DCM and concentrated under reduced pressure. Purification by column chromatography on silica gel using pentane/ $\mathrm{Et}_{2} \mathrm{O}$ as eluent (60/40) afforded the corresponding dialdehyde.

\section{GP2: Horner-Wadsworth-Emmons reaction}

To a stirred solution of $\mathrm{NaH}$ ( $60 \%$ in oil, 4.15 equiv) in THF ( 0.25 $\mathrm{M})$ at $0{ }^{\circ} \mathrm{C}$ was added triethyl phosphonoacetate (4 equiv) dropwise and the mixture was stirred at $\mathrm{rt}$ for $45 \mathrm{~min}$. The dialdehyde (1 equiv) in THF (0.2 M) was then added dropwise at $0{ }^{\circ} \mathrm{C}$. The reaction mixture was stirred at $\mathrm{rt}$ for $12 \mathrm{~h}$ then quenched with saturated $\mathrm{NH}_{4} \mathrm{Cl}$ solution and extracted with DCM. The combined organic layers were dried over $\mathrm{MgSO}_{4}$, filtered and concentrated under reduced pressure. Purification by column chromatography on silica gel using petroleum ether/EtOAc (90/10) as eluent afforded the corresponding diester.

\section{Dimethyl 3,3'-(1,2-phenylenebis(sulfanediyl))(2E,2'E)-diacry-} late (2).

To a stirred solution of $\mathbf{1}$ ( $1.5 \mathrm{~g}, 10.5 \mathrm{mmol}, 1$ equiv) in THF (90 $\mathrm{mL}$ ) at $-78^{\circ} \mathrm{C}$ under argon was added $n \mathrm{BuLi}(11.4 \mathrm{~mL}, 1.95 \mathrm{M}$ in hexanes, 2.1 equiv) dropwise. The yellow solution was stirred at - $78{ }^{\circ} \mathrm{C}$ for $30 \mathrm{~min}$ before being added dropwise to a solution of Methyl (E)-3-iodoacrylate $(4.92 \mathrm{~g}, 23.2 \mathrm{mmol}, 2.2$ equiv) in THF $(30 \mathrm{~mL})$. The reaction mixture was stirred at $-78^{\circ} \mathrm{C}$ for $2 \mathrm{~h}$ then quenched with water $(30 \mathrm{~mL})$, extracted with EtOAc, dried over $\mathrm{MgSO}_{4}$, filtered and concentrated under reduced pressure to afford the desired product ( $3.36 \mathrm{~g}$, quant) as a brown oil. $\mathrm{R}_{\mathrm{f}} 0.30$ $($ PE-EtOAC = 90/10); (ATR) v 2994, 1710, 1582, 1432, 1299, 1260, $1235,1156,1038,944,828,753 ;{ }^{1} \mathrm{H}$ NMR $\left(400 \mathrm{MHz}, \mathrm{CDCl}_{3}\right) \delta$ $7.71(\mathrm{~d}, J=15.1 \mathrm{~Hz}, 2 \mathrm{H}), 7.58(\mathrm{dd}, J=5.8,3.4 \mathrm{~Hz}, 2 \mathrm{H}), 7.44(\mathrm{dd}, J$ $=5.8,3.4 \mathrm{~Hz}, 2 \mathrm{H}), 5.68(\mathrm{~d}, J=15.1 \mathrm{~Hz}, 2 \mathrm{H}), 3.71(\mathrm{~s}, 6 \mathrm{H}) ;{ }^{13} \mathrm{C} \mathrm{NMR}$ $\left(100 \mathrm{MHz}, \mathrm{CDCl}_{3}\right) \delta 165.4(2 \mathrm{C}), 144.9(2 \mathrm{CH}), 134.5(2 \mathrm{C}), 134.2$ $(2 \mathrm{CH}), 130.4(2 \mathrm{CH}), 116.9(2 \mathrm{CH}), 51.7\left(2 \mathrm{CH}_{3}\right)$; HRMS (ESI) calcd for $\mathrm{C}_{14} \mathrm{H}_{14} \mathrm{O}_{4} \mathrm{~S}_{2} \mathrm{Na}\left([\mathrm{M}+\mathrm{Na}]^{+}\right) 333.0226$ found 333.0221 .

\section{(2E,2'E)-3,3'-(1,2-phenylenebis(sulfanediyl))diacrylic acid (2-} $\mathrm{OH})$

To a stirred solution of $2(0.11 \mathrm{~g}, 0.36 \mathrm{mmol}, 1$ equiv) in a mixture of $\mathrm{THF} / \mathrm{H}_{2} \mathrm{O} 3: 1(6.7 \mathrm{~mL})$ under argon was added $\mathrm{LiOH}$ ( $0.043 \mathrm{~g}, 1.79 \mathrm{mmol}, 5$ equiv) at rt. The reaction mixture was 
stirred at $50{ }^{\circ} \mathrm{C}$ for $12 \mathrm{~h}$ without light. The reaction mixture was diluted in water and extracted with DCM. Aqueous layer was acidified to $\mathrm{pH} 2$ and cooled to $0{ }^{\circ} \mathrm{C}$. Precipitate was filtered to afford the desired product $\mathbf{2 - O H}(0.094 \mathrm{~g}, 93 \%$ yield) as white solid. Mp $212{ }^{\circ} \mathrm{C}$; (ATR) v 3017, 2822, 1667, 1579, 1416, 1305, 1264, 1190, 929, 847, 745, 685; ${ }^{1} \mathrm{H}$ NMR (400 MHz, MeOD) $\delta$ $7.77(\mathrm{~d}, J=15.1 \mathrm{~Hz}, 2 \mathrm{H}), 7.69(\mathrm{dd}, J=5.8,3.4 \mathrm{~Hz}, 2 \mathrm{H}), 7.56$ (dd, $J$ $=5.8,3.4 \mathrm{~Hz}, 2 \mathrm{H}), 5.59(\mathrm{~d}, J=15.0 \mathrm{~Hz}, 2 \mathrm{H}) ;{ }^{13} \mathrm{C} \mathrm{NMR}(100 \mathrm{MHz}$, $\left.\mathrm{CDCl}_{3}\right) \delta 168.1(2 \mathrm{C}), 146.6(2 \mathrm{CH}), 135.6(2 \mathrm{C}), 135.5(2 \mathrm{CH}), 131.8$ $(2 \mathrm{CH}), 118.1(2 \mathrm{CH})$; HRMS (ESI) calcd for $\mathrm{C}_{12} \mathrm{H}_{9} \mathrm{O}_{4} \mathrm{~S}_{2}\left([\mathrm{M}-\mathrm{H}]^{-}\right)$ 280.9948 found 280.9948 .

(2E,2'E)-3,3'-(benzene-1,2-diyldisulfanediyl)bisprop-2-enal (3) Prepared according to GP1. Scale $2(2.4 \mathrm{~g}, 7.73 \mathrm{mmol})$; Yield 1.39 g (72\%); Orange solid; $\mathrm{Mp} 106{ }^{\circ} \mathrm{C} ; \mathrm{R}_{\mathrm{f}} 0.15$ (pentane-Et ${ }_{2} \mathrm{O}=$ 60/40); (ATR) v 3020, 2845, 1650, 1545, 1443, 747; ${ }^{1} \mathrm{H}$ NMR (400 $\left.\mathrm{MHz} \mathrm{CDCl}_{3}\right) \delta 9.45(\mathrm{~d}, J=7.6 \mathrm{~Hz}, 2 \mathrm{H}), 7.67(\mathrm{dd}, J=5.8,3.4 \mathrm{~Hz}$, $2 \mathrm{H}), 7.60(\mathrm{~d}, J=15.0 \mathrm{~Hz}, 2 \mathrm{H}), 7.54(\mathrm{dd}, J=5.8,3.4 \mathrm{~Hz}, 2 \mathrm{H}), 5.93$ $(\mathrm{dd}, J=15.1,7.6 \mathrm{~Hz}, 2 \mathrm{H}) ;{ }^{13} \mathrm{C}$ NMR $\left(100 \mathrm{MHz} \mathrm{CDCl}_{3}\right) \delta 189.5$ $(2 \mathrm{CH}), 154.1(2 \mathrm{CH}), 134.7(2 \mathrm{CH}), 133.6(2 \mathrm{C}), 131.0(2 \mathrm{CH}), 127.7$ (2CH); HRMS (ESI) calcd for $\mathrm{C}_{12} \mathrm{H}_{10} \mathrm{O}_{2} \mathrm{~S}_{2} \mathrm{Na}\left([\mathrm{M}+\mathrm{Na}]^{+}\right) 273.0014$ found 273.0017 .

\section{Diethyl (2E,4E,2'E,4'E)-5,5'-(benzene-1,2-diyldisulfanediyl)} bispenta-2,4-dienoate (4)

Prepared according to GP2. Scale $3(0.62 \mathrm{~g}, 2.46 \mathrm{mmol})$; Yield $0.84 \mathrm{~g}(88 \%)$; Yellow solid; $\mathrm{Mp} 97^{\circ} \mathrm{C} ; \mathrm{R}_{\mathrm{f}} 0.18$ (PE-EtOAc = 90/10); $(A T R) ~ v 2980,2359,1700,1618,1557,1464,1364,1265,1225$, $1135,984,747 ;{ }^{1} \mathrm{H}$ NMR $\left(400 \mathrm{MHz}, \mathrm{CDCl}_{3}\right) \delta 7.46$ (dd, $J=5.8,3.4$ $\mathrm{Hz}, 2 \mathrm{H}), 7.35$ (dd, $J=5.8,3.4 \mathrm{~Hz}, 2 \mathrm{H}), 7.28(\mathrm{dd}, J=15.3,11.3 \mathrm{~Hz}$, $2 \mathrm{H}), 6.78(\mathrm{~d}, J=14.8 \mathrm{~Hz}, 2 \mathrm{H}), 6.29(\mathrm{dd}, J=14.8,11.2 \mathrm{~Hz}, 2 \mathrm{H})$, $5.76(\mathrm{~d}, J=15.3 \mathrm{~Hz}, 2 \mathrm{H}), 4.19(\mathrm{q}, J=7.1 \mathrm{~Hz}, 4 \mathrm{H}), 1.28(\mathrm{t}, J=7.1$ $\mathrm{Hz}, 6 \mathrm{H}) ;{ }^{13} \mathrm{C} \mathrm{NMR}\left(100 \mathrm{MHz}, \mathrm{CDCl}_{3}\right) \delta 166.7(2 \mathrm{C}), 142.3(2 \mathrm{CH})$, $135.9(2 \mathrm{CH}), 134.9(2 \mathrm{C}), 131.9(2 \mathrm{CH}), 128.9(2 \mathrm{CH}), 127.9(2 \mathrm{CH})$, $119.4(2 \mathrm{CH}), 60.1\left(2 \mathrm{CH}_{2}\right), 14.2\left(2 \mathrm{CH}_{3}\right)$; HRMS (ESI) calcd for $\mathrm{C}_{20} \mathrm{H}_{22} \mathrm{O}_{4} \mathrm{~S}_{2} \mathrm{Na}\left([\mathrm{M}+\mathrm{Na}]^{+}\right) 413.0852$ found 413.0862 .

\section{(2E,4E,2' $\left.E, 4^{\prime} E\right)-5,5^{\prime}$-(benzene-1,2-diyldisulfanediyl)bispenta-}

\section{2,4-dienal (5)}

Prepared according to GP1. Scale 4 (1.12 g, $2.91 \mathrm{mmol})$; Yield $0.69 \mathrm{~g}$ (79\%); Yellow/orange solid; $\mathrm{Mp} 139{ }^{\circ} \mathrm{C} ; \mathrm{R}_{\mathrm{f}} 0.26$ (PE-EtOAc $=60 / 40) ;(A T R) \vee 2956,1663,1608,1447,1112,981,759 ;{ }^{1} \mathrm{H}$ NMR $\left(400 \mathrm{MHz}, \mathrm{CDCl}_{3}\right) \delta 9.53(\mathrm{~d}, J=7.9 \mathrm{~Hz}, 2 \mathrm{H}), 7.55$ (dd, $J=5.8$, $3.5 \mathrm{~Hz}, 2 \mathrm{H}$ ), 7.43 (dd, $J=5.9,3.4 \mathrm{~Hz}, 2 \mathrm{H}$ ), 7.09 (ddd, $J=15.2$, 11.1, $0.7 \mathrm{~Hz}, 2 \mathrm{H}), 6.97(\mathrm{dt}, J=14.8,0.7 \mathrm{~Hz}, 2 \mathrm{H}$ ), 6.35 (ddd, $J=$ $14.8,11.1,0.7 \mathrm{~Hz}, 2 \mathrm{H}$ ), 6.02 (ddt, $J=15.2,7.9,0.7 \mathrm{~Hz}, 2 \mathrm{H}) ;{ }^{13} \mathrm{C}$ NMR (100 MHz, CDCl $)$ \& $193.4(2 \mathrm{CH}), 149.7(2 \mathrm{CH}), 139.3(2 \mathrm{CH})$, $134.8(2 \mathrm{C}), 133.1(2 \mathrm{CH}), 129.8(2 \mathrm{CH}), 129.7(2 \mathrm{CH}), 126.9(2 \mathrm{CH})$; HRMS (ESI) calcd for $\mathrm{C}_{16} \mathrm{H}_{14} \mathrm{O}_{2} \mathrm{~S}_{2} \mathrm{Na}\left([\mathrm{M}+\mathrm{Na}]^{+}\right) 325.0327$ found 325.0331.

\section{Diethyl 7,7'-(1,2phenylenebis(sulfanediyl))}

\section{(2E,2'E,4E,4'E,6E,6'E)-bis(hepta-2,4,6-trienoate) (6)}

Prepared according to GP2. Scale 5 (0.36 g, $1.20 \mathrm{mmol})$; Yield $0.36 \mathrm{~g}(68 \%)$; Bright yellow solid; Purification by recrystallization in EtOH; Mp $124^{\circ} \mathrm{C}$; $\mathrm{R}_{\mathrm{f}} 0.25$ (PE-EtOAC = 90/10); (ATR) v 2976, 1737, 1621, 1597, 1547, 1444, 1363, 1331, 1249, 1207, 1171, $1133,1037,1005,967,891,835,740 ;{ }^{1} \mathrm{H}$ NMR $\left(400 \mathrm{MHz} \mathrm{CDCl}_{3}\right)$ $\delta 7.43$ (dd, $J=5.8,3.4 \mathrm{~Hz}, 2 \mathrm{H}), 7.31$ (dd, $J=5.8,3.4 \mathrm{~Hz}, 2 \mathrm{H}), 7.27$ (dd, $J=15.6,11.2 \mathrm{~Hz}, 2 \mathrm{H}), 6.56(\mathrm{dd}, J=14.7,10.8 \mathrm{~Hz}, 2 \mathrm{H}), 6.56$ $(\mathrm{d}, J=14.8 \mathrm{~Hz}, 2 \mathrm{H}) 6.32(\mathrm{dd}, J=14.9,10.9 \mathrm{~Hz}, 2 \mathrm{H}), 6.22(\mathrm{dd}, J=$
14.8, $11.4 \mathrm{~Hz}, 2 \mathrm{H}), 5.86(\mathrm{~d}, J=15.2 \mathrm{~Hz}, 2 \mathrm{H}), 4.20(\mathrm{q}, J=7.1 \mathrm{~Hz}$, $4 \mathrm{H}), 1.29(\mathrm{t}, J=7.1 \mathrm{~Hz}, 6 \mathrm{H}) ;{ }^{13} \mathrm{C} \mathrm{NMR}\left(100 \mathrm{MHz}, \mathrm{CDCl}_{3}\right) \delta 167.1$ $(2 \mathrm{C}), 144.2(2 \mathrm{CH}), 138.6(2 \mathrm{CH}), 135.6(2 \mathrm{C}), 131.8(2 \mathrm{CH}), 131.3$ $(2 \mathrm{CH}), 130.6(2 \mathrm{CH}), 129.1(2 \mathrm{CH}), 128.7(2 \mathrm{CH}), 121.3(2 \mathrm{CH}), 60.4$ $\left(2 \mathrm{CH}_{2}\right), 14.5\left(2 \mathrm{CH}_{3}\right)$; HRMS (ESI) calcd for $\mathrm{C}_{24} \mathrm{H}_{26} \mathrm{O}_{4} \mathrm{~S}_{2} \mathrm{Na}$ $\left([\mathrm{M}+\mathrm{Na}]^{+}\right) 465.1165$ found 465.1181 .

\section{Diethyl 7,7'-(1,2-phenylenedisulfonyl)(2E,2'E,4E,4'E,6E,6'E)-}

\section{bis(hepta-2,4,6-trienoate) (6-0)}

To a stirred solution of sulfide 6 ( 1 equiv, $0.10 \mathrm{~g}, 0.22 \mathrm{mmol}$ ) in $\operatorname{DCM}(0.03 \mathrm{M})$ at $0{ }^{\circ} \mathrm{C}$ was added $m$ CPBA $(70 \%, 4.5$ equiv) portion wise and the mixture was stirred at $\mathrm{rt}$ for $12 \mathrm{~h}$. The reaction mixture was quenched at $0{ }^{\circ} \mathrm{C}$ by saturated $\mathrm{Na}_{2} \mathrm{~S}_{2} \mathrm{O}_{3}$ and $\mathrm{Na}_{2} \mathrm{CO}_{3}$ solutions, and extracted with DCM. The combined organic layers were dried over $\mathrm{MgSO}_{4}$, filtered and concentrated under reduced pressure to give the corresponding sulfone 6-0 $0.11 \mathrm{~g}$ (quant.); White solid; $\mathrm{Mp} 149{ }^{\circ} \mathrm{C} ; \mathrm{R}_{\mathrm{f}} 0.66$ (PE-EtOAc = 50/50); $($ ATR) v 2920, 2851, 2361, 2341, 1712, 1624, 1607, 1330, 1313, $1249,1202,1148,1129,1001,848,666,598 ;{ }^{1} \mathrm{H}$ NMR $(400 \mathrm{MHz}$, $\left.\mathrm{CDCl}_{3}\right) \delta 8.24(\mathrm{dd}, J=5.9,3.4 \mathrm{~Hz}, 2 \mathrm{H}), 7.74(\mathrm{dd}, J=5.9,3.4 \mathrm{~Hz}$, $2 \mathrm{H}$ ), 7.33-7.19 (m, 6H), 6.67 (dd, $J=14.9,11.0 \mathrm{~Hz}, 2 \mathrm{H}), 6.56(\mathrm{dd}$, $J=15.1,9.1 \mathrm{~Hz}, 2 \mathrm{H}), 6.01(\mathrm{~d}, J=15.3 \mathrm{~Hz}, 2 \mathrm{H}), 4.16(\mathrm{q}, J=7.1 \mathrm{~Hz}$, $4 \mathrm{H}), 1.23(\mathrm{t}, J=7.1 \mathrm{~Hz}, 6 \mathrm{H}) ;{ }^{13} \mathrm{C} \mathrm{NMR}\left(100 \mathrm{MHz}, \mathrm{CDCl}_{3}\right) \delta 166.1$ (2C), $142.6(2 \mathrm{CH}), 141.8(2 \mathrm{CH}), 140.4(2 \mathrm{C}), 139.8(2 \mathrm{CH}), 134.3$ $(2 \mathrm{CH}), 134.2(2 \mathrm{CH}), 133.2(2 \mathrm{CH}), 132.0(2 \mathrm{CH}), 126.3(2 \mathrm{CH}), 60.7$ $\left(2 \mathrm{CH}_{2}\right), 14.3\left(2 \mathrm{CH}_{3}\right)$; HRMS (ESI) calcd for $\mathrm{C}_{24} \mathrm{H}_{26} \mathrm{O}_{8} \mathrm{~S}_{2} \mathrm{Na}$ $\left([\mathrm{M}+\mathrm{Na}]^{+}\right) 529.0961$ found 529.0982 .

\section{(2E,2'E,4E,4'E,6E,6'E)-7,7'-(1,2-phenylenebis(sulfanediyl))bis} (1-phenylhepta-2,4,6-trien-1-one) (6-COPh)

Prepared according to GP3 using diethyl (2-oxo-2phenylethyl)phosphonate. Purification by recrystallization in EtOH. Scale: 5 (0.10 g, 0.33 mmol); Yield: 0.042 g (54\%); Orange solid; Mp $164{ }^{\circ} \mathrm{C}$; (ATR) v 1660, 1586, 1571, 1545, 1444, 1342, $1259,1185,1145,1016,994,842,767,743,699,664 ;{ }^{1} \mathrm{H}$ NMR $\left(400 \mathrm{MHz}, \mathrm{CDCl}_{3}\right) \delta$ 7.95-7.92 $(\mathrm{m}, 4 \mathrm{H}), 7.57-7.53(\mathrm{~m}, 2 \mathrm{H})$, 7.49-7.48 (m, 2H), 7.47-7.46 (m, $4 \mathrm{H}), 7.45-7.44(\mathrm{~m}, 2 \mathrm{H}), 7.34$ $(\mathrm{dd}, J=5.8,3.4 \mathrm{~Hz}, 2 \mathrm{H}), 6.98(\mathrm{~d}, J=14.8 \mathrm{~Hz}, 2 \mathrm{H}), 6.70$ (dd, $J=$ $14.4,6.9 \mathrm{~Hz}, 2 \mathrm{H}), 6.64(\mathrm{~d}, J=14.8 \mathrm{~Hz}, 2 \mathrm{H}), 6.42-6.35(\mathrm{~m}, 4 \mathrm{H}) ;{ }^{13} \mathrm{C}$ $\operatorname{NMR}\left(100 \mathrm{MHz}, \mathrm{CDCl}_{3}\right) \delta 190.4(2 \mathrm{C}), 144.6(2 \mathrm{CH}), 140.2(2 \mathrm{CH})$, $138.4(2 \mathrm{C}), 135.6(2 \mathrm{C}), 132.8(2 \mathrm{CH}), 132.2(2 \mathrm{CH}), 132.0(2 \mathrm{CH})$, $130.6(2 \mathrm{CH}), 129.8(2 \mathrm{CH}), 128.9(2 \mathrm{CH}), 128.7(4 \mathrm{CH}), 128.5(4 \mathrm{CH})$, $125.3(2 \mathrm{CH})$; HRMS (ESI) calcd for $\mathrm{C}_{32} \mathrm{H}_{26} \mathrm{NaO}_{2} \mathrm{~S}_{2}\left([\mathrm{M}+\mathrm{Na}]^{+}\right)$ 529.1266 found 529.1274

\section{[2+2] photocycloaddition of 2}

2 ( 1 equiv) was dissolved in MeCN $\left(10^{-2} \mathrm{M}\right)$. The bright yellow solution was degassed for $1 \mathrm{~h}$ then irradiated at $\mathrm{rt}$ under argon in the photoreactor Rayonet ( $\lambda=300 \mathrm{~nm}, 16$ light bulbs) for $1 \mathrm{~h}$ and concentrated under reduced pressure to afford a mixture of compounds 2-mix and 7. Ratio was determined by ${ }^{1} \mathrm{H}$ NMR on the crude.

${ }^{1} \mathrm{H} \mathrm{NMR}\left(300 \mathrm{MHz}, \mathrm{CDCl}_{3}\right) \delta$ Characteristic peaks

2-E/E $7.70(d, J=15.1 \mathrm{~Hz}, 2 \mathrm{H}), 5.67(\mathrm{~d}, J=15.1 \mathrm{~Hz}, 2 \mathrm{H})$

2-Z/Z 7.11 (d, $J=10.0 \mathrm{~Hz}, 2 \mathrm{H}), 5.96(\mathrm{~d}, J=10.0 \mathrm{~Hz}, 2 \mathrm{H})$

2-E/Z 7.72 (d, $J=15.0 \mathrm{~Hz}, 1 \mathrm{H}$ ), 7.12 (d, $J=10.1 \mathrm{~Hz}, 1 \mathrm{H}$ ), 5.97 (d, $J=10.1 \mathrm{~Hz}, 2 \mathrm{H}), 5.61(\mathrm{~d}, J=15.0 \mathrm{~Hz}, 1 \mathrm{H})$

7 4.54-4.52 (app-d, $J=5.1 \mathrm{~Hz}, 2 \mathrm{H}$ ), 3.07-3.05 (app-d, $J=5.1 \mathrm{~Hz}$, $2 \mathrm{H})$

[2+2] photocycloaddition in cyclodextrine cavity 
A stirred solution of acyclic compound (1 equiv) and CD (1 equiv) in distilled water $\left(10^{-2} \mathrm{M}\right)$ was degassed under argon for $30 \mathrm{~min}$. The suspension was irradiated while stirring in a photoreactor Rayonet ( $\lambda=300$ or $350 \mathrm{~nm}, 16$ light bulbs) for a reaction time at $r$ under argon. The suspension was then extracted with DCM and EtOAc. The combined organic layers were washed with brine, dried over $\mathrm{MgSO}_{4}$, filtered and concentrated under reduced pressure to afford the corresponding cyclobutane compound.

Dimethyl (1R,2S,2aS,8aR)-1,2,2a,8a-tetrahydrobenzo[b]cyclo buta[e][1,4]dithiine-1,2-dicarboxylate (7)

Prepared using $\beta-C D$. Yellow paste. $R_{f} 0.22$ (PE-EtOAc: 90/10); $(A T R) \vee 2950,2851,1731,1434,1330,1161,1083,750 ;{ }^{1} \mathrm{H}$ NMR $\left(400 \mathrm{MHz}, \mathrm{CDCl}_{3}\right) \delta 7.53(\mathrm{dd}, J=5.7,3.4 \mathrm{~Hz}, 2 \mathrm{H}), 7.28$ (dd, $J=5.7,3.4 \mathrm{~Hz}, 2 \mathrm{H}), 4.55-4.52$ (app-d, $J=5.1 \mathrm{~Hz}, 2 \mathrm{H}), 3.68(\mathrm{~s}, 6 \mathrm{H})$, 3.07-3.05 (m, 2H); $\left.{ }^{13} \mathrm{C} \mathrm{NMR} \mathrm{(100} \mathrm{MHz,} \mathrm{CDCl}_{3}\right) \delta 171.3(2 \mathrm{C}), 135.6$ (2C), $133.1(2 \mathrm{CH}), 128.2(2 \mathrm{CH}), 52.5\left(2 \mathrm{CH}_{3}\right), 47.9(2 \mathrm{CH}), 46.9$ (2CH); HRMS (ESI) calcd for $\mathrm{C}_{14} \mathrm{H}_{14} \mathrm{O}_{4} \mathrm{~S}_{2} \mathrm{Na}\left([\mathrm{M}+\mathrm{Na}]^{+}\right) 333.0226$ found 333.0241 .

(1R,2S,2aS,8aR)-1,2,2a,8a-tetrahydrobenzo[b]cyclobuta[e] [1,4]dithiine-1,2-dicarboxylic acid (7-OH)

Prepared using $\gamma$-CD. Reaction time: $24 \mathrm{~h}$. Scale: 2-OH (0.016 g, $0.057 \mathrm{mmol}$ ); Yield: $0.011 \mathrm{~g}$ (69\%); White solid; Mp $205^{\circ} \mathrm{C}$; (ATR) v 3105, 2924, 1694, 1422, 1246, 1229, 758; ${ }^{1} \mathrm{H}$ NMR $(400 \mathrm{MHz}$ $\left.\mathrm{CDCl}_{3}\right) \delta 7.54(\mathrm{dd}, J=5.7,3.4 \mathrm{~Hz}, 2 \mathrm{H}), 7.32(\mathrm{dd}, J=5.8,3.4 \mathrm{~Hz}$ $2 \mathrm{H}), 4.49-4.447(\mathrm{~m}, 2 \mathrm{H}), 2.97-2.95(\mathrm{~m}, 2 \mathrm{H}) ;{ }^{13} \mathrm{C} N M R(100 \mathrm{MHz}$, $\left.\mathrm{CDCl}_{3}\right) \delta 174.1(2 \mathrm{C}), 137.1(2 \mathrm{C}), 133.8(2 \mathrm{CH}), 129.1(2 \mathrm{CH}), 49.0$ $(2 \mathrm{CH}), 48.5(2 \mathrm{CH})$; HRMS (ESI) calcd for $\mathrm{C}_{12} \mathrm{H}_{10} \mathrm{O}_{4} \mathrm{~S}_{2} \mathrm{Na}\left([\mathrm{M}+\mathrm{Na}]^{+}\right)$ 304.9913 found 304.9918 .

\section{[2+2] photocycloaddition of 4}

4 (0.27 g, $0.69 \mathrm{mmol}, 1$ equiv) was dissolved in MeCN $(69 \mathrm{~mL}$, $\left.10^{-2} \mathrm{M}\right)$. The yellow solution was degassed for $1 \mathrm{~h}$ then irradiated at $\mathrm{rt}$ under argon in the photoreactor Rayonet $(\lambda=$ $300 \mathrm{~nm}, 16$ light bulbs) for $1 \mathrm{~h}$ and concentrated under reduced pressure. Purification by column chromatography on silica gel using pentane/EtOAc (94/6 to 50/50) as eluent afforded the symmetrical isomer product 8-sym $(0.084 \mathrm{~g}, 31 \%$ yield) as a yellow oil and the non-symmetrical isomer 8-dis $(0.057 \mathrm{~g}, 21 \%$ yield) as a colorless oil.

Diethyl 3,3'-(1,2,2a,8a-tetrahydrobenzo[b]cyclobuta[e][1,4] dithiine-1,2-diyl)(2E,2'E)-diacrylate (8-sym)

$R_{f} 0.18$ (pentane-EtOAc = 95/5); (ATR) v 2980, 1713, 1649, 1446 $1367,1266,1157,1095,1033,981,751 ;{ }^{1} \mathrm{H}$ NMR $(400 \mathrm{MHz}$, $\left.\mathrm{CDCl}_{3}\right) \delta 7.51$ (dd, $J=5.7,3.4 \mathrm{~Hz}, 2 \mathrm{H}$ ), 7.27 (dd, $J=5.6,3.6 \mathrm{~Hz}$, $2 \mathrm{H}$ ), 6.86 (ddd, $J=15.6,5.7,2.5 \mathrm{~Hz}, 2 \mathrm{H}$ ), $5.79(\mathrm{~d}, J=15.4,0.8 \mathrm{~Hz}$, $2 \mathrm{H}), 4.18(\mathrm{q}, J=7.1 \mathrm{~Hz}, 4 \mathrm{H}), 4.14-4.12(\mathrm{app}-\mathrm{d}, J=5.0 \mathrm{~Hz}, 2 \mathrm{H})$, 3.08-3.04 (m, 2H) $1.27(\mathrm{t}, J=7.1 \mathrm{~Hz}, 6 \mathrm{H}) ;{ }^{13} \mathrm{C}$ NMR $(100 \mathrm{MHz}$ $\left.\mathrm{CDCl}_{3}\right) \delta 165.8(2 \mathrm{C}), 144.2(2 \mathrm{CH}), 135.7(2 \mathrm{C}), 132.8(2 \mathrm{CH}), 128.0$ $(2 \mathrm{CH}), 123.6(2 \mathrm{CH}), 60.7\left(2 \mathrm{CH}_{2}\right), 49.8(2 \mathrm{CH}), 47.6(2 \mathrm{CH}), 14.4$ $\left(2 \mathrm{CH}_{3}\right)$; HRMS (ESI) calcd for $\mathrm{C}_{20} \mathrm{H}_{22} \mathrm{O}_{4} \mathrm{~S}_{2} \mathrm{Na}\left([\mathrm{M}+\mathrm{Na}]^{+}\right) 413.0852$ found 413.0853 .

Diethyl 3,3'-((1R,2R)-1,2,2a,8a-tetrahydrobenzo[b]cyclobuta [e][1,4]dithiine-1,2-diyl)(2E,2'E)-diacrylate (8-dis)

$R_{f} 0.09$ (pentane-EtOAc = 95/5); (ATR) v 2980, 1711, 1650, 1447, $1367,1267,1156,1036,977,751 ;{ }^{1} \mathrm{H}$ NMR $\left(400 \mathrm{MHz} \mathrm{CDCl}_{3}\right) \delta$ 7.53 (dd, $J=5.9,3.3 \mathrm{~Hz}, 1 \mathrm{H}$ ), 7.45 (dd, $J=5.9,3.2 \mathrm{~Hz}, 1 \mathrm{H}), 7.25$ (dd, $J=5.8,3.4 \mathrm{~Hz}, 2 \mathrm{H}), 6.90(\mathrm{dd}, J=15.6,10.5 \mathrm{~Hz}, 1 \mathrm{H}), 6.88(\mathrm{dd}$,
$J=15.7,9.8 \mathrm{~Hz}, 1 \mathrm{H}), 5.72(\mathrm{dd}, J=15.6,1.5 \mathrm{~Hz}, 1 \mathrm{H}), 5.59(\mathrm{dd}, J=$ 15.7, $1.3 \mathrm{~Hz}, 1 \mathrm{H}$ ), 4.35 (ddd, $J=9.8,8.4,1.2 \mathrm{~Hz}, 1 \mathrm{H}$ ), 4.21-4.14 $(\mathrm{m}, 4 \mathrm{H}), 4.08(\mathrm{dd}, J=9.8,8.9 \mathrm{~Hz}, 1 \mathrm{H}), 3.33(\mathrm{tdd}, J=8.7,7.5,1.3$ $\mathrm{Hz}, 1 \mathrm{H}), 2.68$ (tdt, $J=9.2,6.8,1.4 \mathrm{~Hz}, 1 \mathrm{H}), 1.30-1.25(\mathrm{~m}, 6 \mathrm{H}) ;{ }^{13} \mathrm{C}$ NMR (75 MHz, $\left.\mathrm{CDCl}_{3}\right) \delta 166.1$ (1C), 165.9 (1C), 145.7 (1CH), $144.8(1 \mathrm{CH}), 136.1(1 \mathrm{C}), 135.7(1 \mathrm{C}), 133.1(1 \mathrm{CH}), 132.1(1 \mathrm{CH})$, $128.3(1 \mathrm{CH}), 127.9(1 \mathrm{CH}), 123.0(1 \mathrm{CH}), 122.3(1 \mathrm{CH}), 60.7\left(1 \mathrm{CH}_{2}\right)$, $60.6\left(1 \mathrm{CH}_{2}\right), 51.5(1 \mathrm{CH}), 48.0(1 \mathrm{CH}), 47.6(1 \mathrm{CH}), 45.6(1 \mathrm{CH}), 14.4$ $\left(1 \mathrm{CH}_{3}\right), 14.2\left(1 \mathrm{CH}_{3}\right)$; HRMS (ESI) calcd for $\mathrm{C}_{20} \mathrm{H}_{22} \mathrm{O}_{4} \mathrm{~S}_{2} \mathrm{Na}$ $\left([\mathrm{M}+\mathrm{Na}]^{+}\right) 413.0852$ found 413.0852 .

\section{[2+2] photocycloaddition of 6}

$6(0.22 \mathrm{~g}, 0.51 \mathrm{mmol}, 1$ equiv) was dissolved in MeCN (337 mL, $\left.1,5.10^{-3} \mathrm{M}\right)$. The yellow solution was degassed for $1 \mathrm{~h}$ then irradiated at $\mathrm{rt}$ under argon in the photoreactor Rayonet $(\lambda=$ $350 \mathrm{~nm}, 16$ light bulbs) for $1 \mathrm{~h}$ and concentrated under reduced pressure. Purification by column chromatography on silica gel using pentane/EtOAc (93/7 to 50/50) as eluent afforded the symmetrical isomer product 9 -sym $(0.10 \mathrm{~g}, 45 \%$ yield) as a yellow oil and the non-symmetrical isomer 9-dis (0.056 g, 25\% yield) as a colorless oil.

Diethyl 5,5'-(1,2,2a,8a-tetrahydrobenzo[b]cyclobuta[e][1,4] dithiine-1,2-diyl)(2E,2'E,4E,4'E)-bis(penta-2,4-dienoate) sym)

$R_{f} 0.30$ (pentane-EtOAc $\left.=90 / 10\right)$; (ATR) v 2955, 2870, 1702, $1639,1445,1367,1301,1238,1129,1031,996,749 ;{ }^{1} \mathrm{H}$ $\operatorname{NMR}\left(400 \mathrm{MHz}, \mathrm{CDCl}_{3}\right) \delta 7.53(\mathrm{dd}, J=5.7,3.4 \mathrm{~Hz}, 2 \mathrm{H}), 7.28$ (dd, $J=5.8,3.5 \mathrm{~Hz}, 2 \mathrm{H}), 7.19(\mathrm{dd}, J=15.4,10.5 \mathrm{~Hz}, 2 \mathrm{H}), 6.13(\mathrm{dd}, J=$ $15.1,10.6 \mathrm{~Hz}, 2 \mathrm{H}), 6.06-6.00(\mathrm{~m}, 2 \mathrm{H}) 5.83(\mathrm{~d}, J=15.3 \mathrm{~Hz}, 2 \mathrm{H})$, $4.20(\mathrm{q}, J=7.1 \mathrm{~Hz}, 4 \mathrm{H}), 4.09-4.08$ (app-d, $J=4.9 \mathrm{~Hz}, 2 \mathrm{H}), 3.05-$ $3.00(\mathrm{~m}, 2 \mathrm{H}), 1.29(\mathrm{t}, J=7.1 \mathrm{~Hz}, 6 \mathrm{H}) ;{ }^{13} \mathrm{C} \mathrm{NMR}\left(100 \mathrm{MHz}, \mathrm{CDCl}_{3}\right)$ $\delta 166.9(2 \mathrm{C}), 143.5(2 \mathrm{CH}), 139.7(2 \mathrm{CH}), 136.0(2 \mathrm{C}), 132.8(2 \mathrm{CH})$, $130.3(2 \mathrm{CH}), 127.9(2 \mathrm{CH}), 121.7(2 \mathrm{CH}), 60.5\left(2 \mathrm{CH}_{2}\right), 50.2(2 \mathrm{CH})$, $48.9(2 \mathrm{CH}), 14.4\left(2 \mathrm{CH}_{3}\right)$; HRMS (ESI) calcd for $\mathrm{C}_{24} \mathrm{H}_{26} \mathrm{O}_{4} \mathrm{~S}_{2} \mathrm{Na}$ $\left([\mathrm{M}+\mathrm{Na}]^{+}\right) 465.1165$ found 465.1182 .

Diethyl 5,5'-((1R,2R)-1,2,2a,8a-tetrahydrobenzo[b]cyclobuta [e][1,4]dithiine-1,2-diyl)(2E,2'E,4E,4'E)-bis(penta-2,4-dienoa te) (9-dis)

$R_{f} 0.24$ (pentane-EtOAc $\left.=90 / 10\right) ;(A T R) \vee 2928,1703,1637$, $1615,1446,1366,1300,1236,1130,1033,995,749 ;{ }^{1} \mathrm{H}$ NMR $\left(400 \mathrm{MHz}, \mathrm{CDCl}_{3}\right) \delta 7.52-7.50(\mathrm{~m}, 1 \mathrm{H}), 7.46-7.44(\mathrm{~m}, 1 \mathrm{H})$, 7.26-7.23 (m, 2H), 7.21 -7.18 (m, 1H), 7.17-7.14 (m, 1H), 6.09$6.04(\mathrm{~m}, 3 \mathrm{H}), 5.95(\mathrm{dd}, J=15.3,10.6 \mathrm{~Hz}, 1 \mathrm{H}), 5.81(\mathrm{~d}, J=15.2 \mathrm{~Hz}$, $1 \mathrm{H}), 5.76(\mathrm{~d}, J=15.4 \mathrm{~Hz}, 1 \mathrm{H}), 4.30$ (ddd, $J=9.7,8.4,1.2 \mathrm{~Hz}, 1 \mathrm{H}$ ), 4.22-4.16 (m, 4H), $4.01(\mathrm{dd}, J=9.7,8.9 \mathrm{~Hz}, 1 \mathrm{H}), 3.23(\mathrm{q}, J=8.3$ $\mathrm{Hz}, 1 \mathrm{H}), 2.62(\mathrm{td}, J=9.1,4.6 \mathrm{~Hz}, 1 \mathrm{H}), 1.31-1.25(\mathrm{~m}, 6 \mathrm{H}) ;{ }^{13} \mathrm{C}$ NMR (100 MHz, $\left.\mathrm{CDCl}_{3}\right) \delta 167.1(1 \mathrm{C}), 166.9(1 \mathrm{C}), 143.8(1 \mathrm{CH})$, $143.6(1 \mathrm{CH}), 141.1(1 \mathrm{CH}), 139.9(1 \mathrm{CH}), 136.4(1 \mathrm{C}), 135.9(1 \mathrm{C})$, $133.0(1 \mathrm{CH}), 131.8(1 \mathrm{CH}), 130.0(1 \mathrm{CH}), 129.2(1 \mathrm{CH}), 128.0(1 \mathrm{CH})$, $127.7(1 \mathrm{CH}), 121.6(1 \mathrm{CH}), 121.4(1 \mathrm{CH}), 60.5\left(1 \mathrm{CH}_{2}\right), 60.5\left(1 \mathrm{CH}_{2}\right)$, $52.0(1 \mathrm{CH}), 49.1(1 \mathrm{CH}), 48.1(1 \mathrm{CH}), 47.1(1 \mathrm{CH}), 14.4\left(1 \mathrm{CH}_{3}\right), 14.4$ $\left(1 \mathrm{CH}_{3}\right)$; HRMS (ESI) calcd for $\mathrm{C}_{24} \mathrm{H}_{26} \mathrm{O}_{4} \mathrm{~S}_{2} \mathrm{Na}\left([\mathrm{M}+\mathrm{Na}]^{+}\right) 465.1165$ found 465.1156 .

\section{[2+2] photocycloaddition of 6-0}

6-0 ( $0.10 \mathrm{~g}, 0.20 \mathrm{mmol}, 1$ equiv) was dissolved in MeCN (50 mL, $\left.4.10^{-3} \mathrm{M}\right)$. The white solution was degassed for $1 \mathrm{~h}$ then irradiated at $\mathrm{rt}$ under argon in the photoreactor Rayonet $(\lambda=$ $300 \mathrm{~nm}, 16$ light bulbs) for $1 \mathrm{~h}$ and concentrated under reduced 
pressure. Purification by column chromatography on silica ge using pentane/EtOAc (75/25 to 50/50) as eluent afforded the classical symmetrical isomer product 9-0-sym (0.045 g, 45\% yield) as a white paste, the other symmetrical isomer 9-0-sym' $(0.010 \mathrm{~g}, 10 \%$ yield) as a white paste and the macrocycle 10 ( $0.025 \mathrm{~g}, 25 \%$ yield) as a bright yellow solid.

Diethyl 5,5'-(3,3,8,8-tetraoxido-1,2,2a,8a-tetrahydrobenzo [b]cyclobuta[e][1,4]dithiine-1,2-diyl)(2E,2'E,4E,4'E)-bis(penta2,4-dienoate) (9-0-sym)

$\mathrm{R}_{\mathrm{f}} 0.13$ (pentane-EtOAc $=70 / 30$ ); (ATR) $v$ 2920, 2359, 1716, $1701,1334,1263,1146,1125,1028,772 ;{ }^{1} \mathrm{H}$ NMR $(400 \mathrm{MHz}$, $\left.\mathrm{CDCl}_{3}\right) \delta 8.22(\mathrm{dd}, J=5.8,3.3 \mathrm{~Hz}, 2 \mathrm{H}), 7.93(\mathrm{dd}, J=5.8,3.3 \mathrm{~Hz}$, 2H), 7.19 (dd, $J=15.4,10.9 \mathrm{~Hz}, 2 \mathrm{H}$ ), $6.33(\mathrm{dd}, J=15.3,10.9 \mathrm{~Hz}$, $2 \mathrm{H}), 6.03-5.97(\mathrm{~m}, 2 \mathrm{H}), 5.91(\mathrm{~d}, J=15.4 \mathrm{~Hz}, 2 \mathrm{H}), 4.50-4.48$ (app$\mathrm{d}, J=5.4 \mathrm{~Hz}, 2 \mathrm{H}), 4.20(\mathrm{q}, J=7.1 \mathrm{~Hz}, 4 \mathrm{H}), 3.79-3.73(\mathrm{~m}, 2 \mathrm{H}) 1.29$ $(\mathrm{t}, J=7.1 \mathrm{~Hz}, 6 \mathrm{H}) ;{ }^{13} \mathrm{C} \mathrm{NMR}\left(100 \mathrm{MHz}, \mathrm{CDCl}_{3}\right) \delta 166.6(2 \mathrm{C}), 142.2$ $(2 \mathrm{CH}), 137.3(2 \mathrm{C}), 135.0(2 \mathrm{CH}), 134.7(2 \mathrm{CH}), 132.7(2 \mathrm{CH}), 127.7$ $(2 \mathrm{CH}), 123.6(2 \mathrm{CH}), 61.4(2 \mathrm{CH}), 60.7\left(2 \mathrm{CH}_{2}\right), 41.5(2 \mathrm{CH}), 14.4$ $\left(2 \mathrm{CH}_{3}\right)$; HRMS (ESI) calcd for $\mathrm{C}_{24} \mathrm{H}_{26} \mathrm{O}_{8} \mathrm{~S}_{2} \mathrm{Na}\left([\mathrm{M}+\mathrm{Na}]^{+}\right) 529.0961$ found 529.0982 .

Diethyl 5,5'-((1R,2R)-3,3,8,8-tetraoxido-1,2,2a,8a-tetrahydro benzo[b]cyclobuta[e][1,4]dithiine-1,2-diyl)(2E,2'E,4E,4'E)-bis (penta-2,4-dienoate) (9-0-sym')

Fully characterized as the paranitrophenyl ester derivative

(2E,2'E,4E,4'E)-(3,3,8,8-tetraoxido-1,2,2a,8a-tetrahydro benzo[b]cyclobuta[e][1,4]dithiine-1,2-diyl)bis(penta-2,4diene-5,1-diyl) bis(4-nitrobenzoate) (9-0-sym'-nitroester)

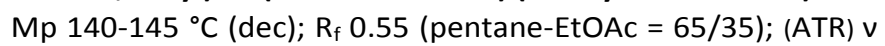
2924, 2854, 1721, 1607, 1525, 1347, 1320, 1269, 1148, 1103, 1014, 991, 873, 719; ${ }^{1} \mathrm{H}$ NMR (400 MHz, $\left.\mathrm{CDCl}_{3}\right) \delta$ 8.30-8.27 (m, $4 \mathrm{H}), 8.23-8.19(\mathrm{~m}, 4 \mathrm{H}), 8.02(\mathrm{dd}, J=6.0,3.3 \mathrm{~Hz}, 2 \mathrm{H}), 7.83(\mathrm{dd}, J$ $=5.9,3.3 \mathrm{~Hz}, 2 \mathrm{H}), 6.41-6.31(\mathrm{~m}, 4 \mathrm{H}), 5.97(\mathrm{dt}, J=14.3,6.3 \mathrm{~Hz}$, $2 \mathrm{H}), 5.90-5.84(\mathrm{~m}, 2 \mathrm{H}), 4.91(\mathrm{dd}, J=6.3,1.2 \mathrm{~Hz}, 4 \mathrm{H}), 4.32-4.30$ (app-d, $J=9.1 \mathrm{~Hz}, 2 \mathrm{H}), 3.72-3.67(\mathrm{~m}, 2 \mathrm{H}) ;{ }^{13} \mathrm{C} \mathrm{NMR}(151 \mathrm{MHz}$, $\left.\mathrm{CDCl}_{3}\right) \delta 164.5(2 \mathrm{C}), 150.8(2 \mathrm{C}), 138.6(2 \mathrm{C}), 135.5(2 \mathrm{C}), 134.2$ $(2 \mathrm{CH}), 133.2(2 \mathrm{CH}), 133.0(2 \mathrm{CH}), 130.9(4 \mathrm{CH}), 129.7(2 \mathrm{CH}), 128.6$ $(2 \mathrm{CH}), 125.4(2 \mathrm{CH}), 123.7(4 \mathrm{C}), 65.7\left(2 \mathrm{CH}_{2}\right), 59.0(2 \mathrm{CH}), 45.8$ (2CH); HRMS (ESI) calcd for $\mathrm{C}_{34} \mathrm{H}_{28} \mathrm{~N}_{2} \mathrm{O}_{12} \mathrm{~S}_{2}\left([\mathrm{M}+\mathrm{Na}]^{+}\right) 743.0976$ found 743.0973 .

Diethyl (5aR,6E,8E,10R,11R,12E,14E,15aR)-5a,10,11,15a-tetra hydrobenzo[b]cyclododeca[e][1,4]dithiine-10,11-dicarboxyla te 5,5,16,16-tetraoxide (10)

$\mathrm{Mp} 97^{\circ} \mathrm{C} ; \mathrm{R}_{\mathrm{f}} 0.35$ (pentane-EtOAc = 70/30); (ATR) v 2922, 2360, $1714,1644,1317,1147,1133,1108,1028,994,688,620 ;{ }^{1} \mathrm{H}$ $\operatorname{NMR}\left(400 \mathrm{MHz}, \mathrm{CDCl}_{3}\right) \delta 8.11$ (dd, $\left.J=5.9,3.3 \mathrm{~Hz}, 2 \mathrm{H}\right), 7.86$ (dd, $J=6.0,3.3 \mathrm{~Hz}, 2 \mathrm{H}$ ), $6.21(\mathrm{dd}, J=15.7,10.4 \mathrm{~Hz}, 2 \mathrm{H}), 5.92(\mathrm{dd}, J=$ $15.7,10.4 \mathrm{~Hz}, 2 \mathrm{H}), 5.45-5.39(\mathrm{~m}, 2 \mathrm{H}), 5.38-5.32(\mathrm{~m}, 2 \mathrm{H}), 4.69$ (dd, $J=7.1,2.8 \mathrm{~Hz}, 2 \mathrm{H}), 4.21(\mathrm{q}, J=7.2 \mathrm{~Hz}, 4 \mathrm{H}), 3.46$ (dd, $J=7.5$, $2.9 \mathrm{~Hz}, 2 \mathrm{H}), 1.31-1.27(\mathrm{t}, \mathrm{J}=7.1 \mathrm{~Hz}, 6 \mathrm{H}) ;{ }^{13} \mathrm{C} \mathrm{NMR}(100 \mathrm{MHz}$, $\left.\mathrm{CDCl}_{3}\right) \delta 171.5(2 \mathrm{C}), 143.5(2 \mathrm{CH}), 137.2(2 \mathrm{CH}), 137.2(2 \mathrm{C}), 134.4$ $(2 \mathrm{CH}), 132.3(2 \mathrm{CH}), 125.3(2 \mathrm{CH}), 117.9(2 \mathrm{CH}), 68.6(2 \mathrm{CH}), 61.7$ $\left(2 \mathrm{CH}_{2}\right), 53.8(2 \mathrm{CH}), 14.3\left(2 \mathrm{CH}_{3}\right)$; HRMS (ESI) calcd for $\mathrm{C}_{24} \mathrm{H}_{26} \mathrm{O}_{8} \mathrm{~S}_{2} \mathrm{Na}\left([\mathrm{M}+\mathrm{Na}]^{+}\right) 529.0961$ found 529.0975 .

Acknowledgements
The authors thank UPMC, CNRS and IUF. This work was supported by LabEx MiChem (Ph. D. grant for SG) part of French state funds managed by the ANR within the Investissements d'Avenir programme under reference ANR-11-IDEX-0004-02. A postdoctoral research grant to $M B$ from the department of science and technology of the French embassy in Germany is gratefully acknowledged. We also warmly thank Prof. JeanPierre Desvergne (U. Bordeaux) for helpful discussions.

\section{Notes and references}

¥ CCDC 4: 1535549, CCDC 5: 1535551, CCDC 6: 1535552, CCDC 6-0: 1535553, 7-OH: 1535554, 10: 1535555.

\#The quantum yield of the reaction of $\mathbf{2}$ was determined by chemical actinometry and was found to be $0.3 \%$, much lower than for the corresponding diene and triene systems $\mathbf{4}$ and $\mathbf{6}$ which showed quantum yields above $50 \%$. The actinometer used was Hopf's monoene derivative 2 from: H. Greiving, $H$. Hopf, P. G. Jones, P. Bubenitschek, J.-P. Desvergne, H. BouasLaurent, Liebigs Ann. 1995, 1949.

1 (a) H. Hopf, J. F. Liebman and H. M. Perks in Cubanes, fenestranes, ladderanes, prismanes, staffanes and other oligocyclobutanoids, PATAl's Chemistry of Functional Groups, 2009, DOI: 10.1002/9780470682531.pat0337; (b) D. H. Nouri and D. J. Tantillo, Curr. Org. Chem. 2006, 10, 2055; (c) R. N. Warrener, G. Abbenante and C. H. L. Kennard, J. Am. Chem. Soc. 1994, 116, 3645.

2 (a) W. Li and M. A. Fox, J. Am. Chem. Soc. 1996, 118, 11752; (b) G. Mehta, M. B. Viswanath, G. N. Sastry, E. D. Jemmis,; D. S. K. Reddy and A. C. Kunwar, Angew. Chem. Int. Ed. 1992, 31, 1488; (c) T. Friscic, L. Klasinc, B. Kovac and L. R. MacGillivray, J. Phys. Chem. A 2008, 112, 1493; (d) D. J. Tantillo and R. Hoffman, Angew. Chem. Int. Ed. 2002, 41, 1033; (e) J. P. Wagner and P. R. Schreiner, J. Chem. Theory Comput. 2014, 10, 1353.

3 (a) L.A. Van Niftrik, J.A. Fuerst, J.S. Sinninghe Damsté, J.G. Kuenen, M.S.M. Jetten and M. Strous, FEMS Microbiol. Lett., 2004, 233, 7; (b) L. Van Niftrik, W.J.C. Geerts, E.G. van Donselaar, B.M. Humbel, A. Yakushevska, A. J. Verkleij, M.S.M. Jetten and M. Strous, J. Struct. Biol., 2008, 161, 401.

4 (a) M.M.M. Kuypers, et al., Nature, 2003, 422, 608; (b) T. Dalsgaard, B. Thamdrup and D. E. Canfield, Res. Microbiol., 2005, 156, 457

5 V. Mascitti and E. J. Corey, J. Am. Chem. Soc. 2004, 126, 15664. 6 V. Mascitti, E. J. Corey, J. Am. Chem. Soc. 2006, 128, 3118.

7 J. S. Sinninghe Damsté, M. Strous, W. I. C. Rijpstra, E. C. Hopmans, J. A. J. Geenevasen, A. C. T. Van Duin, L. A. Van Niftrik and M. S. M. Jetten, Nature, 2002, 419, 708.

8 J. A. M. Mercer, C. M. Cohen, S. R. Shuken, A. M. Wagner, M. W. Smith, F. R. Moss, M. D. Smith, R. Vahala, A. GonzalezMartinez, S. G. Boxer and N. Z. Burns, J. Am. Chem. Soc., 2016, 138, 15845.

9 For important reviews and monograph on synthetic photochemistry: (a) N. Hoffmann, Chem. Rev. 2008, 108, 1052; (b) Handbook of Synthetic Photochemistry Eds. A. Albini and M. Fagnoni Wiley VCH Weinheim 2010; (c) S. Poplata, A. Tröster, Y.-Q. Zou and T. Bach, Chem. Rev. 2016, 116, 9748.

10 For historical syntheses of ladderanes via consecutive [2+2] cycloadditions: (a) M. Avram, M., I. G. Dinulescu, E. Marica, G. Mateescu, E. Sliam and C. D. Nenitzescu, Chem. Ber. 1964, 97, 382; (b) Y. Li, K. N. Houk, J. Am. Chem. Soc. 1996, 118, 880; (c) Mehta, G.; Viswanath, M. B.; Kunwar, A. C. J. Org. Chem. 1994, 59, 6131; (d) H.-D. Martin, B. Mayer, M. Pütter, M. and H. Höchstetter, Angew. Chem. Int. Ed. 1981, 20, 677; (e) H.-D. 
Martin and M. Hekman, Angew. Chem. Int. Ed. 1973, 12, 572; (f) See ref. 1(c).

11 J. Meinwald, J. Mioduski, Tetrahedron Lett. 1974, 15, 3839.

12 (a) H. Greiving, H. Hopf, P. G. Jones, P. Bubenitschek, J. P. Desvergne and H. Bouas-Laurent, Chem. Commun., 1994, 1075; (b) V. Mascitti and E. J. Corey, Tetrahedron Lett. 2006, 47, 5879 .

13 (a) H. Hopf, H. Greiving, P. G. Jones, P. Bubenitschek, Angew. Chem. Int. Ed., 1995, 34, 683; (b) H. Greiving, H. Hopf, P. G. Jones, P. Bubenitschek, J.-P. Desvergne and H. Bouas-Laurent, Eur. J. Org. Chem., 2005, 558.

14 X. Gao, X.; T. Friscic, T. and L. R. MacGillivray, Angew. Chem. Int. Ed. 2004, 43, 232.

15 (a) L. R. MacGillivray, J. L. Reid and J. A. Ripmeester, J. Am. Chem. Soc., 2000, 122, 7817; (b) G. S. Papaefstathiou, Z. Zhong, L. Geng and L. R. MacGillivray, J. Am. Chem. Soc., 2004 126, 9158.

16 (a) J. C. Santos, and P. Fuentealba, Chem. Phys. Letters 2003, 377, 449; (b) D. H. Nouri, D. J. Tantillo, Org. Biomol. Chem. 2012, 10, 5514.

17 For some evidence of DFT limitations in cyclization reactions, see: S. P. T. Matsuda, W. K. Wilson and Q. Xiong, Org. Biomol. Chem. 2006, 4, 530. We thank one referee for pointing this work.

18 T. Steiner Crystallography Reviews 1996, 6, 1.

19 In the syn-trans-anti stereochemical assignment, the syn term refers to the stereochemistry of the internal cyclobutane bond which is created, the trans term to the stereochemistry of one alkene partner and the anti term to the stereochemistry of the distal cyclobutane bond which is created, see: The Chemistry of Cyclobutanes Parts $1 \& 2$, S. Patai, Z. Rappoport Eds, John Wiley \& Sons, Chichester, 2015.

20 (a) B. S. Green, M. Lahav and G. M. J. Schmidt, J. Chem. Soc. B, 1971, 1552; see also ref. 13b.

21 (a) R. G. Solomon and J. K. Kochi, J. Am. Chem. Soc. 1973, 95, 1889; for representative examples of $[2+2]$ cycloadditions see: (b) R. G. Salomon, D. J. Coughlin, S. Ghosh and G. Zagorski, J. Am. Chem. Soc. 1982, 104, 4, 998; (c) G. Oba, G. Moreira, G. Manuel, M; Koenig, J. Organomet. Chem. 2002, 643-644, 324 (d) I. Braun, F. Rudroff, M. D. Mihovilovic and T. Bach, T. Angew. Chem. Int. Ed. 2006, 45, 5541.

22 (a) A. Juris, V. Balzani, F. Barigelletti, S. Campagna, P. Belser, A. Von Zelewsky, Coord. Chem. Rev. 1988, 84, 85. (b) H. Ikezawa, C. Kutal, K. Yasufuku and H. Yamazaki, J. Am. Chem. Soc. 1986, 108, 1589. (c) Y.-Q. Zou, S.-W. Duan, X.-G. Meng, X.-Q Hu, S. Gao, J.-R. Chen and W.-J. Xiao, Tetrahedron 2012, 68, 6914.

23 Z. Lu, Z. and T. P. Yoon, Angew. Chem. Int. Ed. 2012, 51, 10329

24 L. Harmand, S. Cadet, B. Kauffmann, L. Scarpantonio, P. Batat, G. Jonusauskas, N. D. McClenaghan, D. Lastécouères and J. M. Vincent, Angew. Chem. Int. Ed. 2012, 51, 7137.

25 (a) M. A. Ischay, M. E. Anzovino, J. Du and T. P. Yoon, J. Am Chem. Soc. 2008, 130, 12886; (b) E. L. Tyson, E. P. Farney and T. P. Yoon, Org. Lett. 2012, 14, 1110.

26 V. Ramamurthy, A. Parthasarathy, Isr. J. Chem. 2011, 51, 817.

27 M. V. S. N. Maddipatla, M. Pattabiraman, A. Natarajan, K. Srivastav, J. T. Mague and V. Ramamurthy, Org. Biomol. Chem. 2012, 10, 9219.

28 Gaussian 09, Revision A.02, M. J. Frisch, G. W. Trucks, H. B. Schlegel, G. E. Scuseria, M. A. Robb, J. R. Cheeseman, G. Scalmani, V. Barone, G. A. Petersson, H. Nakatsuji, X. Li, M. Caricato, A. Marenich, J. Bloino, B. G. Janesko, R. Gomperts, B. Mennucci, H. P. Hratchian, J. V. Ortiz, A. F. Izmaylov, J. L. Sonnenberg, D. Williams-Young, F. Ding, F. Lipparini, F. Egidi, J. Goings, B. Peng, A. Petrone, T. Henderson, D. Ranasinghe, V. G. Zakrzewski, J. Gao, N. Rega, G. Zheng, W. Liang, M. Hada, M. Ehara, K. Toyota, R. Fukuda, J. Hasegawa, M. Ishida, T. Nakajima, Y. Honda, O. Kitao, H. Nakai, T. Vreven, K. Throssell,
J. A. Montgomery, Jr., J. E. Peralta, F. Ogliaro, M. Bearpark, J. J. Heyd, E. Brothers, K. N. Kudin, V. N. Staroverov, T. Keith, R. Kobayashi, J. Normand, K. Raghavachari, A. Rendell, J. C. Burant, S. S. Iyengar, J. Tomasi, M. Cossi, J. M. Millam, M. Klene, C. Adamo, R. Cammi, J. W. Ochterski, R. L. Martin, K. Morokuma, O. Farkas, J. B. Foresman, and D. J. Fox, Gaussian, Inc., Wallingford CT, 2016.

29 (a) B3LYP: A. D. Becke, J. Chem. Phys. 1993, 98, 5648. (b) mPWPW91 C. Adamo and V. Barone, J. Chem. Phys. 1998, 108 664.

30 G. D. Purvis III and R. J. Bartlett, .J. Chem.Phys. 1982, 76, 1910. 